\title{
Study of effect of phosphate and uranium ions on the thermal properties of surfactant-modified natural red clay using TG-FTIR-MS techniques
}

\author{
Dariusz Sternik $^{1}$ (D) Agnieszka Gładysz-Płaska ${ }^{1} \cdot$ Ewelina Grabias $^{2} \cdot$ Marek Majdan $^{1} \cdot$ Waldemar Knauer $^{3}$
}

Received: 27 February 2018/Accepted: 29 July 2018/Published online: 16 August 2018

(C) The Author(s) 2018

\begin{abstract}
Products of sorption of uranyl ions on HDTMA-red clay in the presence of phosphates were characterized by thermal analysis. It was established on the basis of DTG curves of the sorption products and FTIR spectra of the gaseous phase of sorption products decomposition that the thermal stability of the mineral increased when $\mathrm{P}(\mathrm{V})$ ions were sorbed along with U(VI) ions, i.e., the temperature of defragmentation/oxidation of surfactant increased when going from U(VI)-HDTMAclay to U(VI)-P(V)-HDTMA-clay to P(V)-HDTMA-clay. The DSC curves of the sorption products showed that defragmentation/oxidation was an exothermic process and dehydration and dehydroxylation had an endothermic character. The investigated sorption system has practical importance, since an evident increase in U(VI) sorption over the entire pH range is observed when going from U(VI)-HDTMA-clay to U(VI)-P(V)-HDTMA-clay.
\end{abstract}

Keywords Uranium - Phosphate - Sorption - HDTMA · Red clay

\section{Introduction}

Organoclays are widely used as adsorbents in the industry and in waste treatment [1-5]. The potential application of organically modified clays in the removal of $U(V I)$ ions from the aqueous phase has been reported by many authors [6-12] and is very important from the practical viewpoint, especially with respect to decontamination of nuclear wastes [13-22] and use of barrier materials in radioactive waste repositories [23, 24]. The use of unmodified clays in repositories is limited due to the fact that waste disposed in those facilities releases not only cationic nuclides (Cs-137, Sr-90, Co-60) but also anionic ones (Se-79, Tc-99, I-129), whose retention by clay minerals is reduced due to

Dariusz Sternik

dsternik@poczta.umcs.lublin.pl

1 Faculty of Chemistry, Maria Curie Skłodowska University, 3 M. Curie Skłodowska Sq., 20-031 Lublin, Poland

2 Faculty of Mathematics, Physics and Computer Science, Maria Curie Skłodowska University, 20-031 Lublin, Poland

3 NETZSCH-Gerätebau GmbH, Wittelsbacherstrasse 42, 95100 Selb, Germany electrostatic repulsion. Surface modification with organic surfactants markedly improves the ability of clays to absorb anionic contaminants [25].

Intercalation of cationic surfactants changes the surface properties of clays from hydrophilic to hydrophobic and enables their industrial application, dependent on their structural properties [26, 27]. Worth mentioning is a study by Bickford and Foote [28]. Those authors synthesized sorbents capable of solidifying Purex, Pubex, and Cleanex organic wastes from the nuclear industry. Two of these sorbents, Petroset II and organoclay, were very easy to work with, as they had been designed to solidify liquid waste without the need for mixing. The Petroset II-G sorbent testing resulted in an optimized waste-loading ratio of 3.44:1 (sorbent to surrogate), and the optimized ratio for organoclay was $2.53: 1$.

The aim of this present study was to examine the influence of phosphate ions on the thermal stability of complexes obtained through the adsorption of uranium (VI) on natural red clay modified with hexadecyltrimethylammonium bromide (HDTMA). In our recent paper, we showed that HDTMA-modified clay effectively sorbed $\mathrm{U}(\mathrm{VI})$ ions in the presence of phosphates [29]. In that study, we tried to characterize the complexes formed 
during the interaction of $\mathrm{U}(\mathrm{VI})$ ions with $\mathrm{P}(\mathrm{V})$ ions on the sorbent surface. To complement these data, we now used the thermogravimetric method coupled with MS and FTIR spectra of the gaseous phase to analyze the U(VI) sorption products, expecting to find an explanation for the mechanism of interaction of the surfactant with $\mathrm{P}(\mathrm{V})$ ions and its gradual decomposition with rise in temperature. Our investigation was also intended to update the excellent studies by Yariv et al. [30-34] and Frost [35-37] concerning thermal analysis of organoclays, with information on new ligands complexing $\mathrm{U}(\mathrm{VI})$ ions.

\section{Experimental}

\section{Preparation of the clays}

A sodium form of red clay, designated as Na-clay, was prepared by equilibration of a raw clay product (R-clay) kindly provided by Geolmin (composition: $\mathrm{SiO}_{2} 64.79 \%$, $\mathrm{Al}_{2} \mathrm{O}_{3} 16.26 \%, \mathrm{Fe}_{2} \mathrm{O}_{3} 7.22 \%, \mathrm{MgO} 2.38 \%$, K2O 2.68\%, $\mathrm{CaO} 0.4 \%$, $\mathrm{TiO} 20.91 \%, \mathrm{MnO} 0.09 \%$ ) with a $\mathrm{NaCl}$ (SigmaAldrich, 99.99\% purity) solution [38]. Organoclays were prepared by equilibration of $1 \mathrm{~g}$ Na-clay with aqueous solutions of hexadecyltrimethylammonium bromide (HDTMA-Br, Sigma-Aldrich, 98\% purity) for $6 \mathrm{~h}$ at $60{ }^{\circ} \mathrm{C}$. The initial concentrations of HDTMA-Br $\left([\text { HDTMA }]_{\text {in }}\right)$ in the aqueous phase were $0.0001,0.001$, and $0.01 \mathrm{~mol} \mathrm{dm}^{-3}$. The concentration of $\mathrm{C}$ in 2-mg samples of organoclays was determined using a Perkin-Elmer $2400 \mathrm{C} \mathrm{H} \mathrm{N}$ analyzer. The molar concentration of the $\mathrm{HDTMA}^{+}$cation in the samples (cHDTMA \% CEC), corresponding to the number of $\mathrm{HDTMA}^{+}$moles per $1 \mathrm{~g}$ of the inorganic part of the samples, was calculated [12]. The cation exchange capacity of Na-clay, determined by the cobalt hexamine complex method [39], was $0.0005 \mathrm{~mol} \mathrm{~g}^{-1}$.

\section{FTIR analysis}

FTIR spectra of HDTMA-clay samples were recorded in the transmission mode at room temperature by means of a 1725X Perkin-Elmer instrument using the $\mathrm{KBr}$ pellet technique (1:20) at a resolution of $2 \mathrm{~cm}^{-1} . \mathrm{KBr}$ was dried at $200{ }^{\circ} \mathrm{C}$ for $24 \mathrm{~h}$, and then, $560 \mathrm{mg} \mathrm{KBr}$ was homogenized with a HDTMA-clay sample in a ball grinder (Narva Brand-Erbisdorf, Germany). Tablets (radius, $1 \mathrm{~cm}$; thickness, $0.1 \mathrm{~cm}$ ) were prepared using a hydraulic press.

\section{Thermal decomposition spectra}

The thermal stability of samples was determined using the device of STA 449 Jupiter F1 (Netzsch, Germany) coupled online with mass spectrometer QMS 403D Aeölos
(Netzsch, Germany) and FTIR spectrometer (Bruker, Germany). The measurement conditions were described in detail in our earlier work $[29,40]$. The samples (mass $\sim 21 \mathrm{mg}$ ) were heated at the rate $10{ }^{\circ} \mathrm{C} \mathrm{min}^{-1}$ in the temperature range of $30-950{ }^{\circ} \mathrm{C}$ in atmosphere of synthetic air $\left(50 \mathrm{~mL} \mathrm{~min}{ }^{-1}\right)$ in an alumina crucible. An empty $\mathrm{Al}_{2} \mathrm{O}_{3}$ crucible was used as a reference. Data were collected and processed using the NETZSCH Proteus ${ }^{\circledR}$ software, version 6.1. The NIST library database was used for mass spectra analysis.

\section{$\mathrm{U}(\mathrm{VI})$ sorption in the presence of $\mathrm{P}(\mathrm{V})$ ions under altered $\mathrm{pH}$ conditions}

$0.1 \mathrm{~g}$ of HDTMA-clay was contacted for $6 \mathrm{~h}$, using a mechanical shaker, with $0.1 \mathrm{dm}^{3}$ aqueous phase composed of $0.0005 \mathrm{~mol} \mathrm{dm}^{-3}\left(\mathrm{UO}_{2}\right)_{3}\left(\mathrm{CH}_{3} \mathrm{COO}\right)_{2} 2 \mathrm{H}_{2} \mathrm{O}$ (98\% purity, Lacheman, p. Brno), $0.0001 \mathrm{~mol} \mathrm{dm}{ }^{-3} \mathrm{Na}_{2} \mathrm{HPO}_{4}$ (p.a., POCH, Poland), and $0.05 \mathrm{~mol} \mathrm{dm}{ }^{-3} \mathrm{CH}_{3} \mathrm{COONa} 3 \mathrm{H}_{2} \mathrm{O}$ (p.a., $\mathrm{POCH}$, Poland). The initial $\mathrm{pH}$ of the aqueous phase was controlled by the addition of $\mathrm{HCl}$ or $\mathrm{NaOH}$. After $6 \mathrm{~h}$, the equilibrated phases were left to separate for $12 \mathrm{~h}$, and then, the equilibrium $\mathrm{pH}\left(\mathrm{pH}_{\mathrm{eq}}\right)$ was measured with a glass electrode after centrifugation of the aqueous phase. The concentration of U(VI) in the aqueous phase was measured spectrophotometrically according to the Arsenazo III method [41].

\section{Results and discussion}

The conditions under which the organoclays were prepared are given in Table 1.

\section{Thermal characterization of sorption products}

In the case of unmodified materials, three endothermic peaks on DSC curves are observed (Fig. 1). The first peak representing a mass loss of $0.68 \%$, with a minimum at about $60.4{ }^{\circ} \mathrm{C}$, is due to the removal of physically adsorbed water [38]. In the second stage $\left(300-750{ }^{\circ} \mathrm{C}\right.$, a minimum at $516.6^{\circ} \mathrm{C}$ ), the mass loss of $3.8 \%$ corresponds to the dehydroxylation of the clay and the thermal polymorph transition $(\alpha \rightarrow \beta)$ of quartz [42, 43].

TG/DTG/DSC curves of HDTMA-clay for the initial HDTMA concentrations of 0.0001 [HDTMA $(0.0001)]$, 0.001 [HDTMA(0.001)], and $0.01 \quad[\operatorname{HDTMA}(0.01)]$ mol dm${ }^{-3}$ are shown in Fig. 2. Endothermic dehydration of the clay is observed in the first region of the curves up to $200{ }^{\circ} \mathrm{C}$. For HDTMA (0.01), a sharp exothermic peak evidences a phase transition of the surfactant, known as chain melting $[35,44]$. The second region of the curves, from 200 to $450{ }^{\circ} \mathrm{C}$, probably represents exothermic defragmentation/oxidation of the surfactant. For HDTMA 
Table 1 Conditions of synthesis of the analyzed organoclays

\begin{tabular}{|c|c|c|c|c|c|}
\hline \multirow[t]{2}{*}{ Sample } & \multicolumn{3}{|c|}{ Initial concentration of reagents $/ \mathrm{mol} \mathrm{dm}^{-3}$} & \multirow[t]{2}{*}{$\mathrm{HDTMA}_{\mathrm{S}} / \mathrm{mmol} \mathrm{g}^{-1}$} & \multirow[t]{2}{*}{ Surfactant in clays/vs. $\%$ CEC } \\
\hline & {$[\text { HDTMA }]_{\text {in }}$} & {$[\mathrm{U}(\mathrm{VI})]_{\text {in }}$} & {$\left[\mathrm{HPO}_{4}{ }^{2-}\right]_{\text {in }}$} & & \\
\hline Na-clay & - & - & - & & \\
\hline \multirow[t]{3}{*}{ HDTMA-clay } & 0.0001 & - & - & 0.09 & 18.82 \\
\hline & 0.001 & - & - & 0.18 & 38.78 \\
\hline & 0.01 & - & - & 1.94 & 863.46 \\
\hline \multirow[t]{3}{*}{ U(VI)-HDTMA-clay } & 0.0001 & 0.0005 & - & 0.07 & 15.14 \\
\hline & 0.001 & 0.0005 & - & 0.27 & 57.40 \\
\hline & 0.01 & 0.0005 & - & 1.57 & 570.26 \\
\hline \multirow[t]{3}{*}{ P(V)-HDTMA-clay } & 0.0001 & - & 0.01 & 0.13 & 26.49 \\
\hline & 0.001 & - & 0.01 & 0.15 & 30.38 \\
\hline & 0.01 & - & 0.01 & 0.25 & 53.02 \\
\hline \multirow[t]{3}{*}{ U(VI)-P(V)-HDTMA-clay } & 0.0001 & 0.0005 & 0.01 & 0.11 & 22.92 \\
\hline & 0.001 & 0.0005 & 0.01 & 0.34 & 75.91 \\
\hline & 0.01 & 0.0005 & 0.01 & 0.44 & 100.34 \\
\hline
\end{tabular}

$C E C$ the cation exchange capacity

Fig. 1 TG, DTG, and DSC curves of red clay

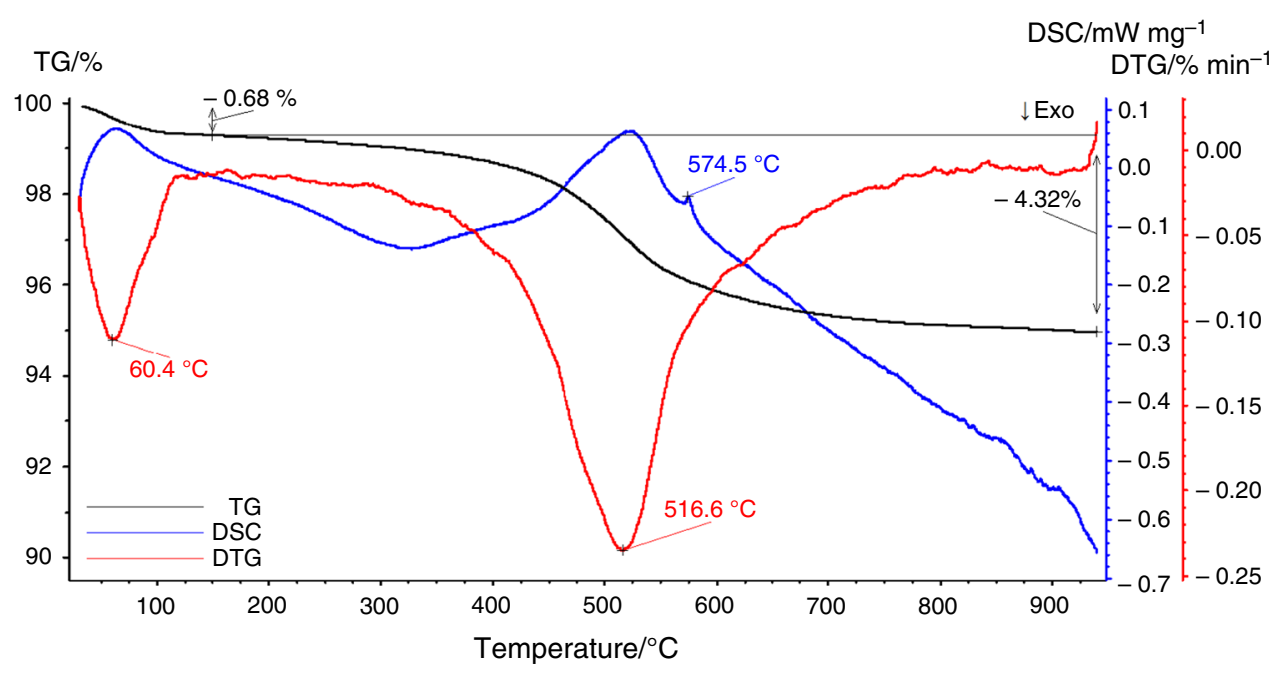

(0.0001), only one peak is visible, at $334.5^{\circ} \mathrm{C}$, whereas for HDTMA (0.001), two peaks are observed, at 252.8 and $334.1{ }^{\circ} \mathrm{C}$ : The first of these two peaks is probably related to nonelectrostatically bound $\mathrm{HDTMA}^{+}$cations forming the bilayer of the sorbent surface, whereas the second one originates from surfactant cations attracted via electrostatic forces by the clay's aluminosilicate framework. For HDTMA (0.01), three peaks are visible, at 237.5, 264.2, and $320.6{ }^{\circ} \mathrm{C}$, which are probably the result of a very complex aggregation of the surfactant accompanying the formation of the bilayers and micelles on the sorbent surface. The third region in the curves, extending from 400 to $900{ }^{\circ} \mathrm{C}$, refers to endothermic oxidation/dehydroxylation of the clay and the $\alpha$ - to $\beta$-form quartz polymorph transition (only for the samples with low concentration of surfactant). The temperature of dehydroxylation shifts from
520 to 515 to $410^{\circ} \mathrm{C}$, which is a reflection of the expansion of the structural skeleton of the clay by spaciously extended HDTMA $^{+}$. There is an overlap between dehydroxylation and oxidation of the surfactant in the case of HDTMA (0.01), because the overall process is exothermic. For U(VI)-HDTMA-clay (Fig. 3), the arrangement of the peaks is very similar to that for HDTMA-clay, i.e., the region of defragmentation/oxidation consists of two peaks for HDTMA (0.001)-U(VI) and three peaks for HDTMA (0.01)-U(VI). There is, however, a clear drop in the dehydration temperature from 91.5 to $72.9^{\circ} \mathrm{C}$ and in the defragmentation/oxidation temperature from 318.1 to $235.6^{\circ} \mathrm{C}$. Moreover, the dehydroxylation temperature decreases from 517.5 to $423.8^{\circ} \mathrm{C}$ as a result of the expansion of the aluminosilicate framework of the clay under the influence of the increasing amount of surfactant 
Fig. 2 TG (a), DTG (b), and DSC (c) curves of HDTMAclay for different the initial concentrations of HDTMA: $\mathrm{Co}=0.0001 \mathrm{~mol} \mathrm{dm}^{-3}$ (green line), $\mathrm{Co}=0.001 \mathrm{~mol} \mathrm{dm}^{-3}$ (red line), $\mathrm{Co}=0.01 \mathrm{~mol} \mathrm{dm}^{-3}$ (black line). (Color figure online) (a)

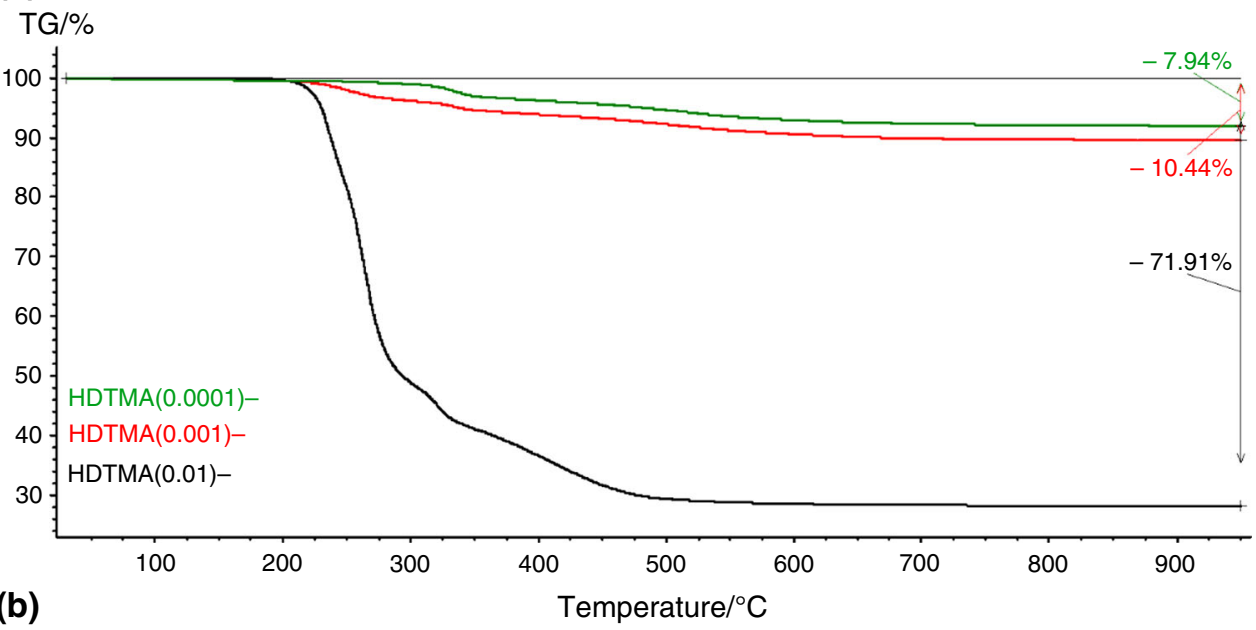

DTG/\% $\min ^{-1}$

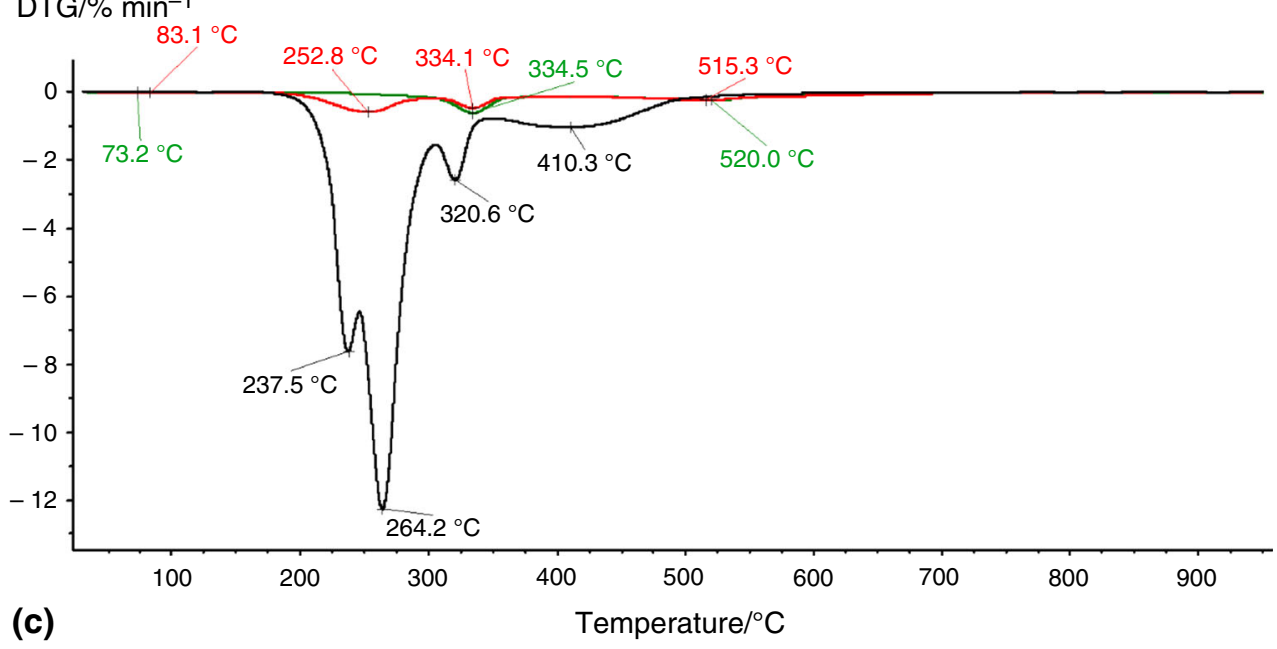

$\mathrm{DSC} / \mathrm{mW} \mathrm{mg}^{-1}$

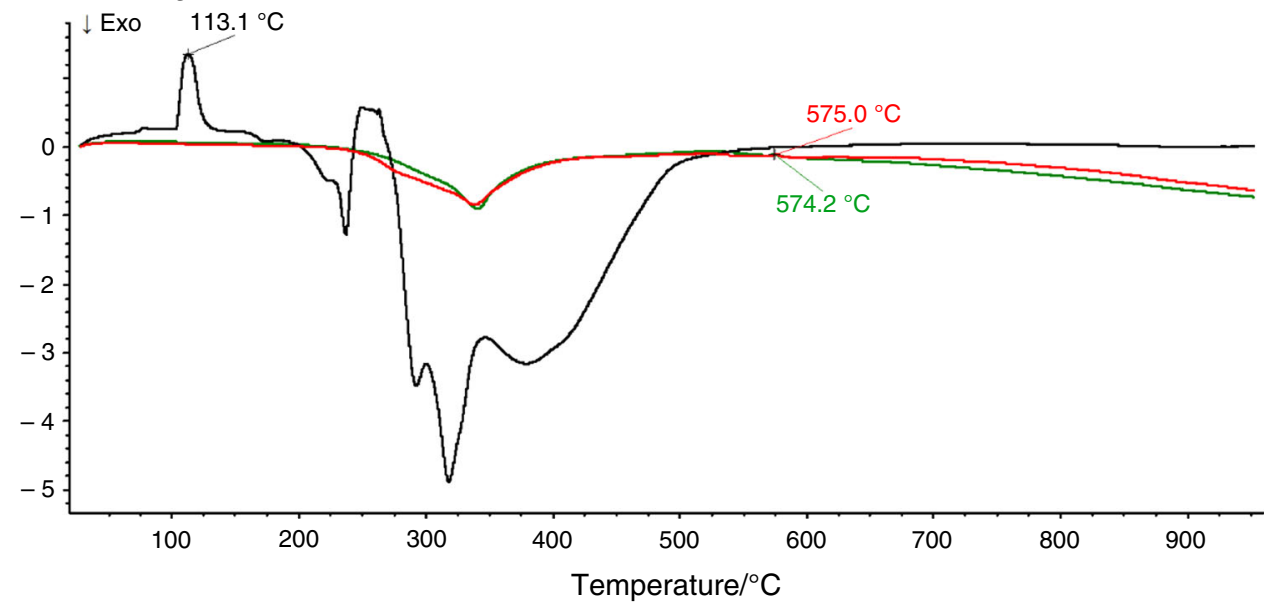

cations filling the interior of the clay structure. Endothermic dehydroxylation is observed for HDTMA (0.0001)$\mathrm{U}(\mathrm{VI})$ and HDTMA(0.001)-U(VI) and exothermic dehydroxylation (due to overlapping of the dehydroxylation with the surfactant oxidation) for $\operatorname{HDTMA}(0.01)-\mathrm{U}(\mathrm{VI})$. For U(VI)-P(V)-HDTMA-clay (Fig. 4), the endothermic dehydration temperature decreases steadily from 107.2 to $88.8^{\circ} \mathrm{C}$ with increasing surfactant concentration. The dehydration temperature is evidently higher when compared with that for the HDTMA-clay and HDTMA-U(VI)clay systems, owing to the strong hydrophilicity of both $\mathrm{U}(\mathrm{VI})$ and $\mathrm{P}(\mathrm{V})$ ions. The defragmentation/oxidation 
Fig. 3 TG (a), DTG (b), and DSC (c) curves of HDTMA$\mathrm{U}(\mathrm{VI})$-clay for different the initial concentrations of HDTMA:

$\mathrm{Co}=0.0001 \mathrm{~mol} \mathrm{dm}^{-3}$ (green line), $\mathrm{Co}=0.001 \mathrm{~mol} \mathrm{dm}^{-3}$ (red line), $\mathrm{Co}=0.01 \mathrm{~mol} \mathrm{dm}^{-3}$ (black line). (Color figure online)

\section{(a)}

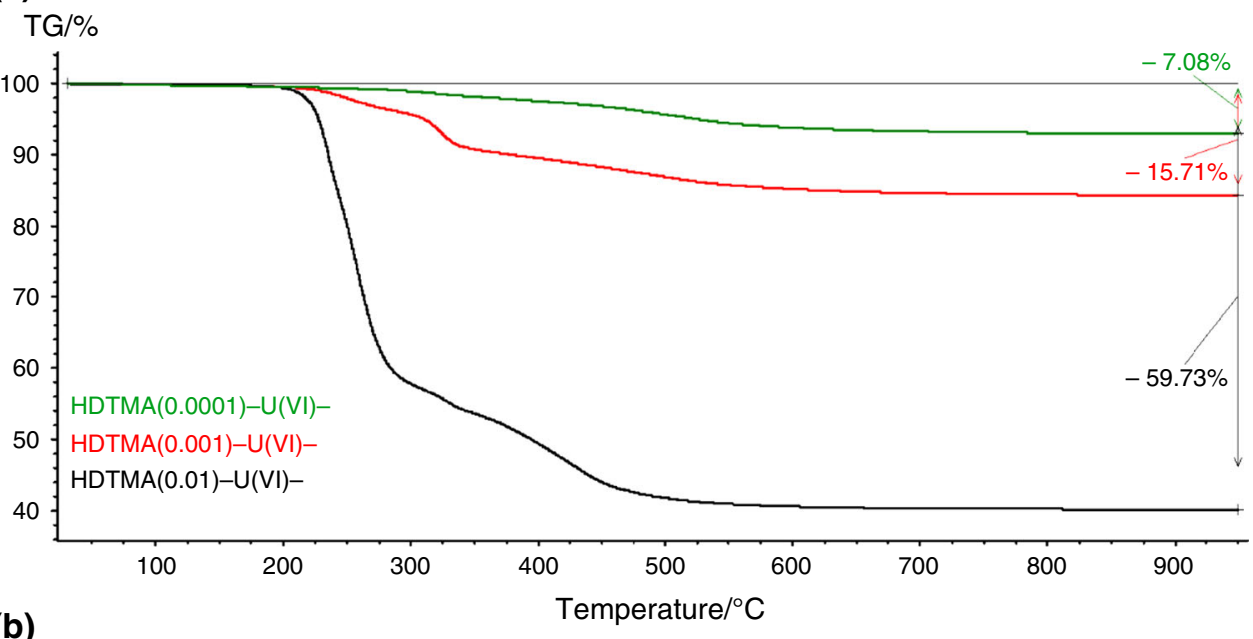

(b) DTG/\% $\min ^{-1}$

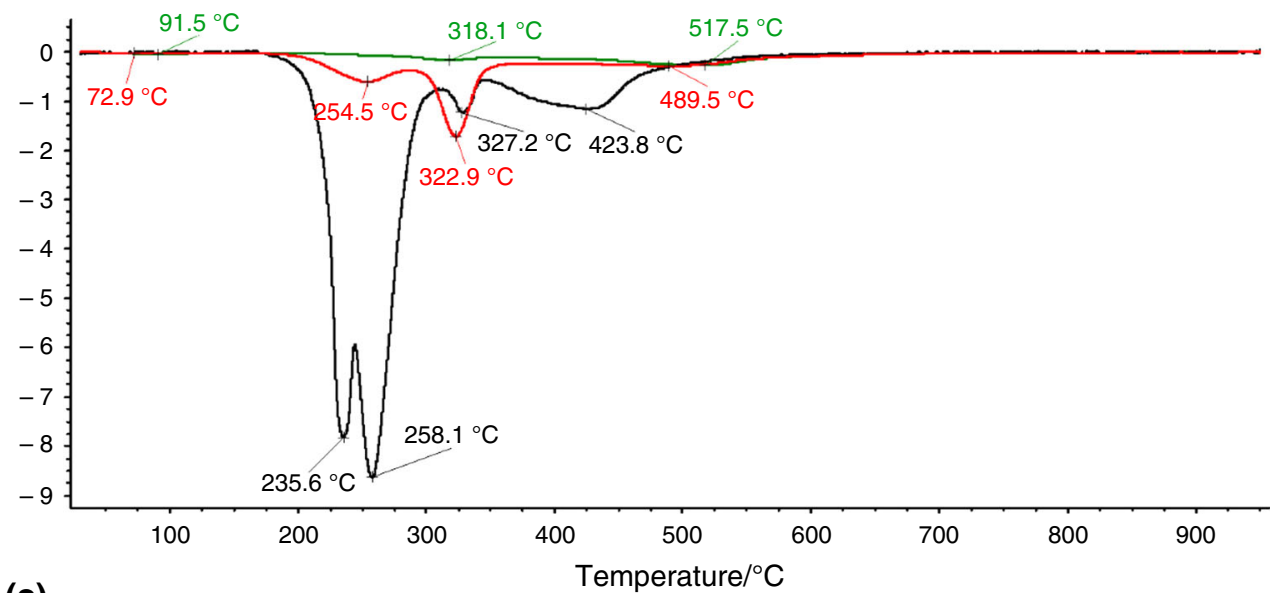

(c)

$\mathrm{DSC} / \mathrm{mW} \mathrm{mg}^{-1}$

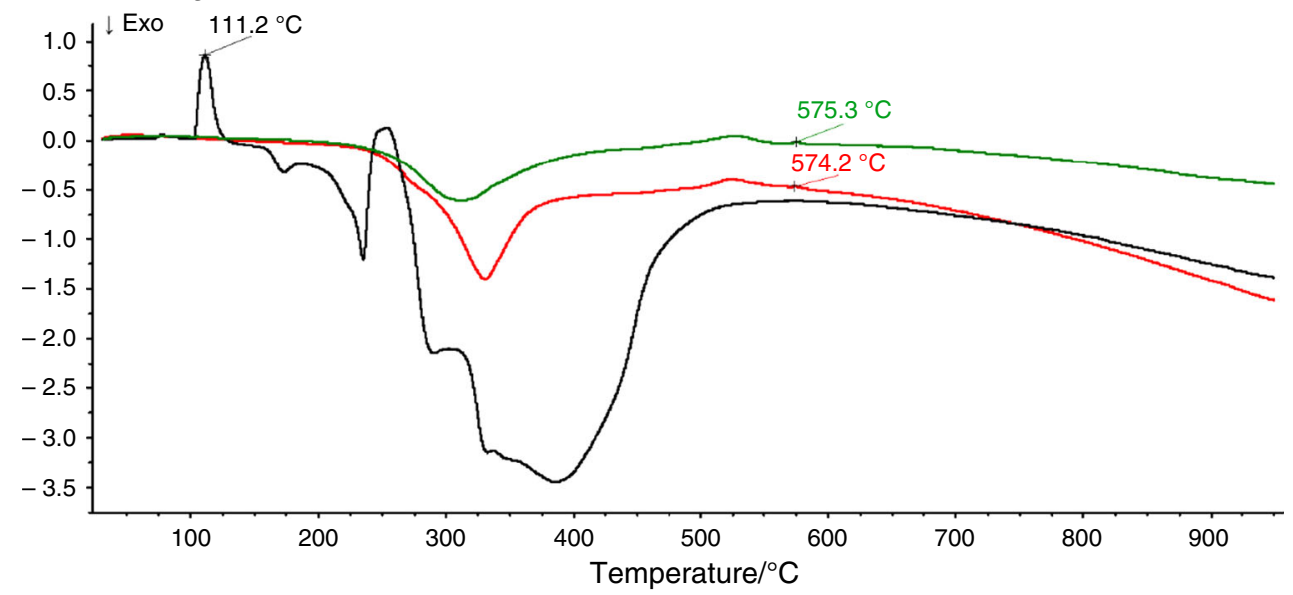

process for the $\mathrm{U}(\mathrm{VI})-\mathrm{P}(\mathrm{V})-\mathrm{HDTMA}$-clay system is more complex than in the case of U(VI)-HDTMA-clay, with three/four peaks observed in the region from 200 to $450{ }^{\circ} \mathrm{C}$, at $246.5,321.7,439.1 ; 222.5,270.8,324.7,437.2$; and $247.3,321.8,437.5^{\circ} \mathrm{C}$. These peaks appear at higher temperatures than those observed for U(VI)-HDTMA-clay. This is presumably, because $\mathrm{U}(\mathrm{VI})$ phosphate complexes interact with the surfactant intercalated in the clay structure, which also manifests itself in the weak decrease in the dehydroxylation temperature from 520.5 to $515.9{ }^{\circ} \mathrm{C}$. It 


\section{(a)}

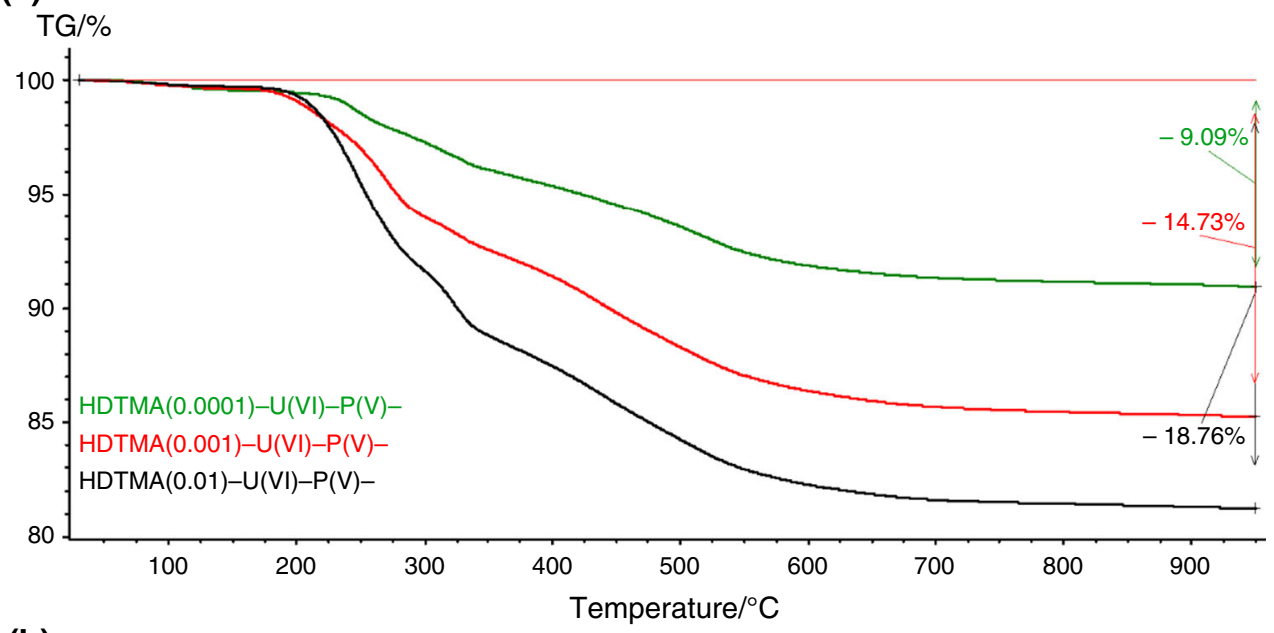

(b)

$\mathrm{DTG} / \% \mathrm{~min}^{-1}$

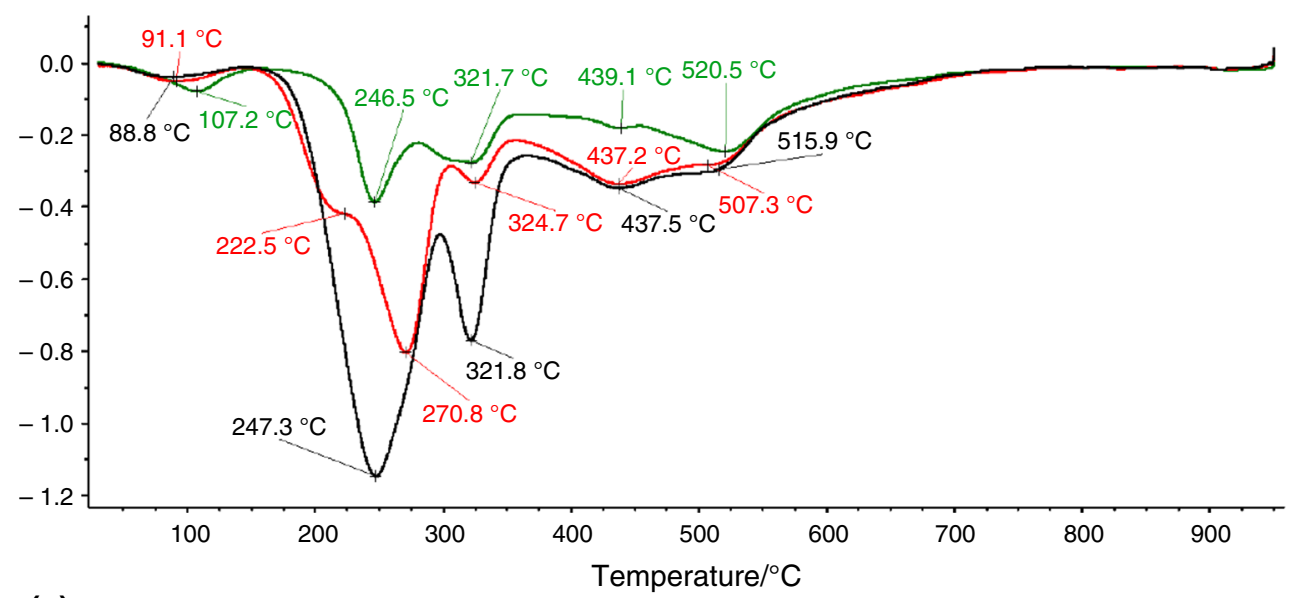

(c)

\section{$\mathrm{DSC} / \mathrm{mW} \mathrm{mg}^{-1}$}

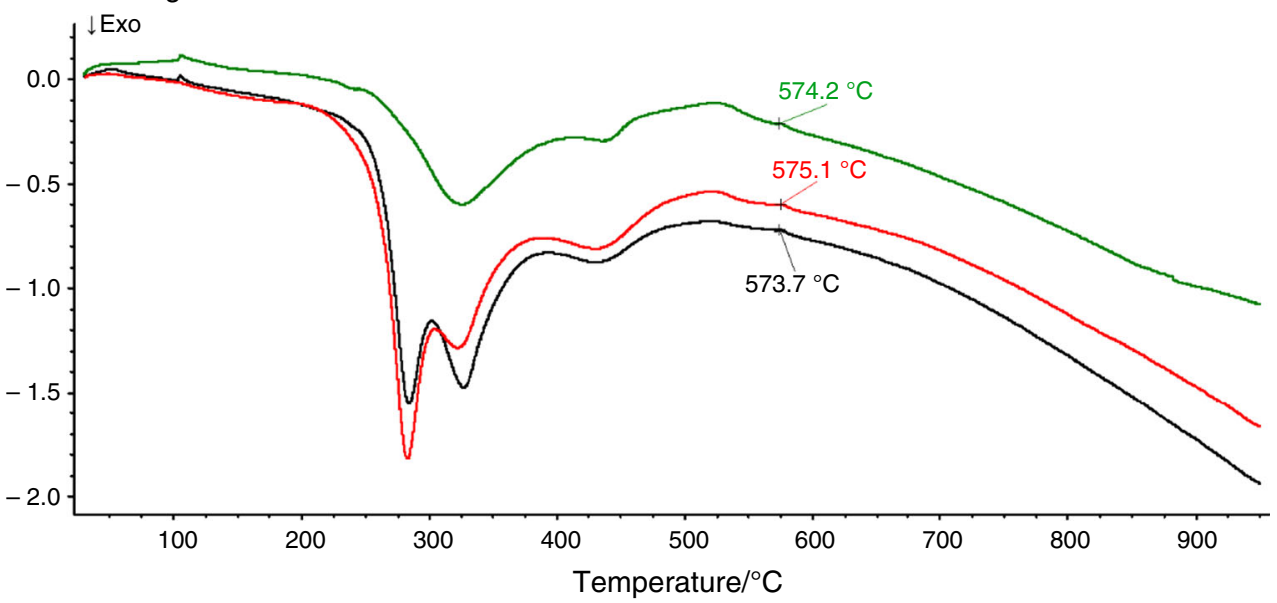

Fig. 4 TG (a), DTG (b), and DSC (c) curves of HDTMA-U(VI)-P(V)-clay for different the initial concentrations of HDTMA: $\mathrm{Co}=0.0001 \mathrm{~mol} \mathrm{dm}^{-3}$ (green line), $\mathrm{Co}=0.001 \mathrm{~mol} \mathrm{dm}^{-3}$ (red line), $\mathrm{Co}=0.01 \mathrm{~mol} \mathrm{dm}^{-3}$ (black line). (Color figure online)

seems that the interaction of the U(VI) phosphate complex with the surfactant counteracts the interaction between the surfactant and the clay matrix. The curve of $\mathrm{P}(\mathrm{V})-$
HDTMA-clay shows clearly that the interaction of $\mathrm{P}(\mathrm{V})$ ions with the surfactant cations is stronger than the interaction between surfactant cations and the clay matrix. 
Fig. 5 TG (a), DTG (b), and DSC (c) curves of HDTMA$\mathrm{P}(\mathrm{V})$-clay for different the initial concentrations of HDTMA:

$\mathrm{Co}=0.0001 \mathrm{~mol} \mathrm{dm}^{-3}$ (green line), $\mathrm{Co}=0.001 \mathrm{~mol} \mathrm{dm}^{-3}$ (red line), $\mathrm{Co}=0.01 \mathrm{~mol} \mathrm{dm}^{-3}$ (black line). (Color figure online) (a)

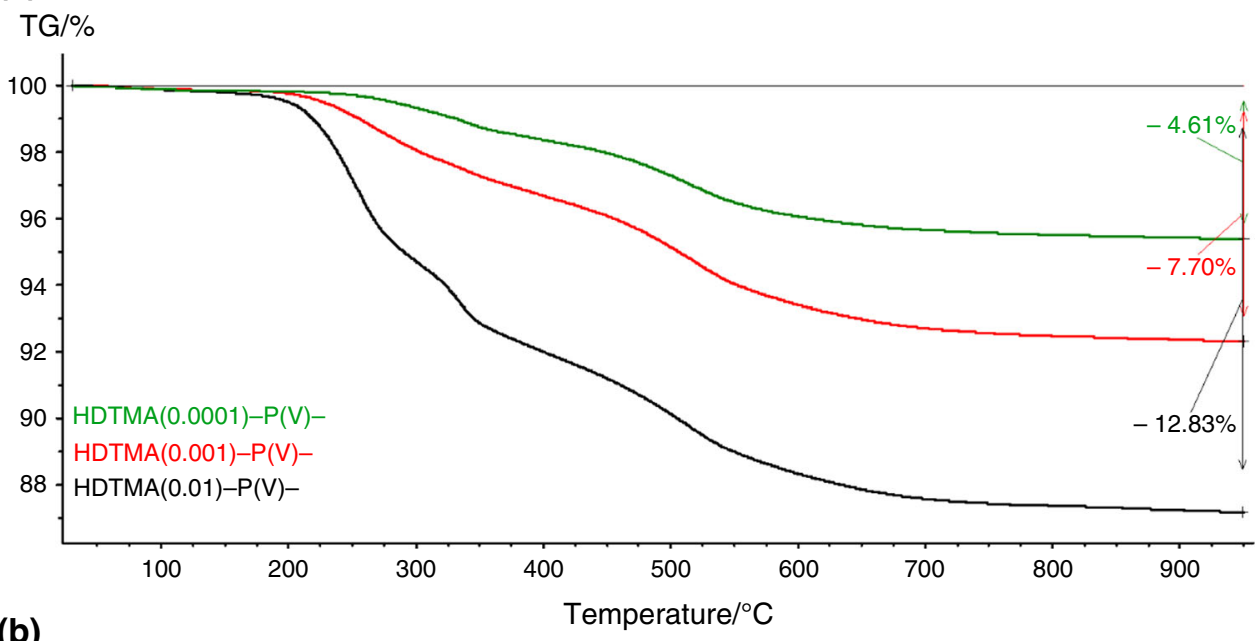

(b)

DTG $/ \% \min ^{-1}$

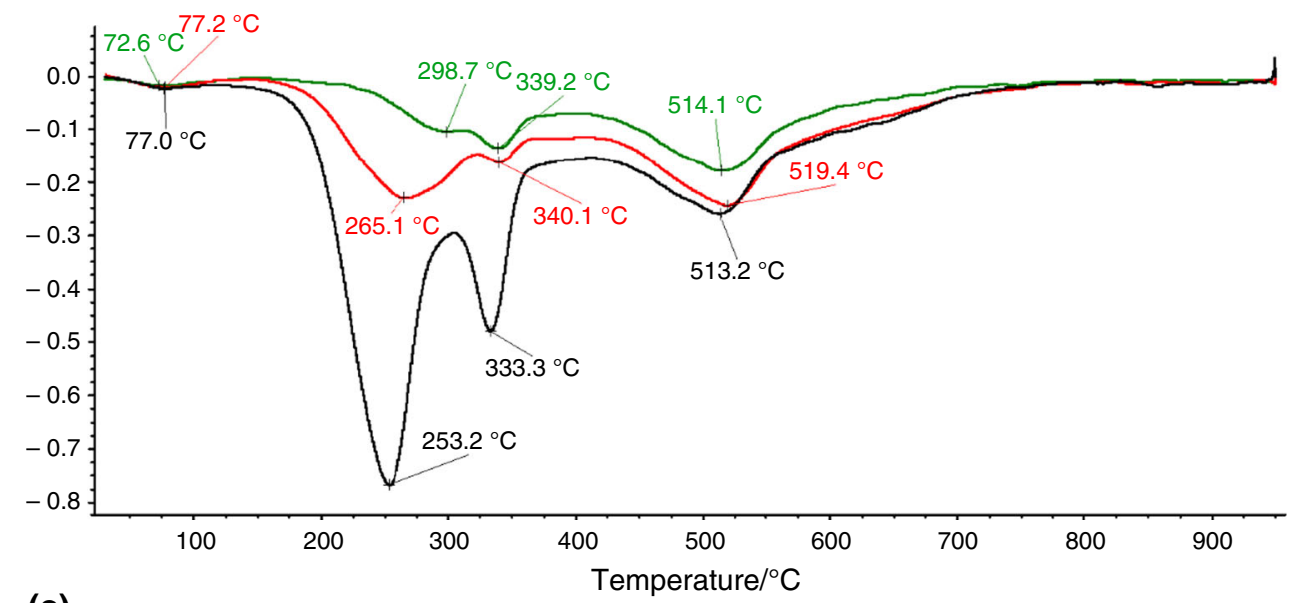

(c)

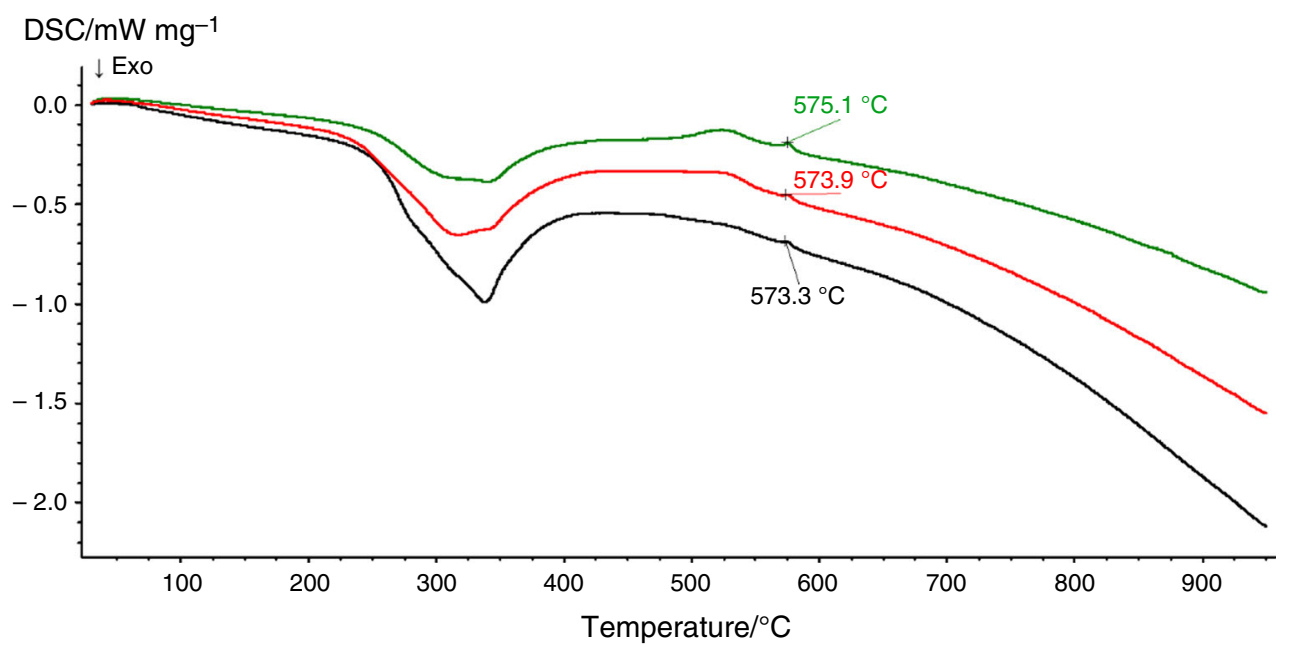


Table 2 Thermal behavior of studied samples

\begin{tabular}{|c|c|c|c|c|c|}
\hline Sample & $\begin{array}{l}\text { Thermal } \\
\text { range/ }{ }^{\circ} \mathrm{C}\end{array}$ & $\begin{array}{l}\text { Mass } \\
\text { loss/ \% }\end{array}$ & $T_{\text {peak }}^{\mathrm{DTG}\left(\mathrm{DSC}^{*}\right)} /{ }^{\circ} \mathrm{C}$ & $\begin{array}{l}\text { Reaction } \\
\text { enthalpy/J g }\end{array}$ & Assignment \\
\hline \multirow[t]{2}{*}{ Red clay } & $30-150$ & 0.68 & 60.4 & 38.72 & Adsorbed and interlayer water elimination \\
\hline & $150-950$ & 4.32 & $516.6\left(574.5^{* \mathrm{q}}\right)$ & $190.7\left(0.75^{\mathrm{q}}\right)$ & Dehydroxylation and quartz polymorph transition \\
\hline \multirow[t]{3}{*}{ HDTMA (0.0001)- } & $30-150$ & 0.27 & 73.2 & 21.51 & Water elimination \\
\hline & $150-420$ & 3.66 & 334.5 & -323.2 & Decomposition and burning of organics \\
\hline & $420-950$ & 4.01 & $520\left(574.2^{*} \mathrm{q}\right)$ & $57.18\left(0.88^{\mathrm{q}}\right)$ & Dehydroxylation/quartz polymorph transition \\
\hline \multirow[t]{3}{*}{ HDTMA (0.001)- } & $30-120$ & 0.14 & 83.1 & 14.52 & Adsorbed and interlayer water elimination \\
\hline & $120-420$ & 6.21 & $252.8 ; 334,1$ & -365.9 & Defragmentation/oxidation of surfactant \\
\hline & $420-950$ & 4.1 & $515.3\left(575^{* \mathrm{q}}\right)$ & $23.58\left(1.22^{\mathrm{q}}\right)$ & $\begin{array}{l}\text { Dehydroxylation/quartz polymorph transition and } \\
\text { burning of organics }\end{array}$ \\
\hline \multirow[t]{3}{*}{ HDTMA (0.01)- } & $30-150$ & 0.01 & $\left(113.1^{* \mathrm{~S}}\right)$ & 95.29 & $\begin{array}{l}\text { Structural rearrangements in alkyl chains of } \\
\text { surfactant }\end{array}$ \\
\hline & $150-245$ & 14.40 & $\left(170.8^{*}\right) ; 237.5$ & $-6.42 ;-101.9$ & Defragmentation/oxidation of surfactant \\
\hline & $245-950$ & 57.50 & $264.2 ; 320.6 ; 410.3$ & $98.75 ;-3128$ & $\begin{array}{l}\text { Melting of organic (melting point from Sigma- } \\
\text { Aldrich data-248-251 }{ }^{\circ} \mathrm{c} \text { ), overlapping of the } \\
\text { dehydroxylation with the surfactant oxidation }\end{array}$ \\
\hline \multirow[t]{3}{*}{ HDTMA (0.0001)-U(VI)- } & $30-165$ & 0.39 & 91.5 & 18.61 & Adsorbed and interlayer water elimination \\
\hline & $165-425$ & 2.43 & 318.1 & -294.6 & Decomposition and burning of organics \\
\hline & $425-950$ & 4.25 & $517.5\left(575.3^{*} \mathrm{q}\right)$ & $59.58\left(0.90^{\mathrm{q}}\right)$ & Dehydroxylation/quartz polymorph transition \\
\hline \multirow[t]{3}{*}{ HDTMA (0.001)-U(VI)- } & $30-175$ & 0.34 & 72.9 & 11.22 & Water elimination \\
\hline & $175-425$ & 10.74 & $254.5 ; 322.9$ & -406.2 & Decomposition and burning of organics \\
\hline & $425-950$ & 4.63 & $489.5\left(574.2^{* \mathrm{q}}\right)$ & $52.21\left(0.53^{\mathrm{q}}\right)$ & $\begin{array}{l}\text { Dehydroxylation/quartz polymorph transition and } \\
\text { oxidation of charcoal }\end{array}$ \\
\hline \multirow[t]{3}{*}{ HDTMA (0.01)-U(VI)- } & $30-150$ & 0.18 & $\left(111.2^{* \mathrm{~S}}\right)$ & 66.1 & $\begin{array}{l}\text { Water elimination and structural rearrangements in } \\
\text { alkyl chains of surfactant }\end{array}$ \\
\hline & $150-245$ & 16.31 & 235.6 & -96.18 & Defragmentation/oxidation of surfactant \\
\hline & $245-950$ & 43.24 & $258.1 ; 327.2 ; 423.8$ & $82.82 ;-2145$ & $\begin{array}{l}\text { Melting of organic, overlapping of the } \\
\text { dehydroxylation with the surfactant oxidation }\end{array}$ \\
\hline \multirow[t]{3}{*}{ HDTMA (0.0001)-U(VI)-P(V)- } & $30-150$ & 0.46 & 107.2 & 16.79 & Adsorbed and interlayer water elimination \\
\hline & $150-440$ & 4.85 & $246.5 ; 321.7 ; 439.1$ & -198.6 & Decomposition and burning of organics \\
\hline & $440-950$ & 3.79 & $520.5\left(574.2^{* \mathrm{q}}\right)$ & $88.53\left(0.33^{\mathrm{q}}\right)$ & Dehydroxylation/quartz polymorph transition \\
\hline \multirow[t]{3}{*}{ HDTMA (0.001)-U(VI)-P(V)- } & $30-150$ & 0.36 & 91.8 & 4.139 & Water elimination \\
\hline & $150-480$ & 10.77 & $222.5 ; 270.8 ; 324.7 ; 437.2$ & $-461.6 ;-37.39$ & Decomposition and burning of organics \\
\hline & $480-950$ & 3.61 & $507.3\left(575.1^{*} \mathrm{q}\right)$ & $29.2\left(0.83^{\mathrm{q}}\right)$ & $\begin{array}{l}\text { Dehydroxylation/quartz polymorph transition and } \\
\text { burning of organics }\end{array}$ \\
\hline \multirow[t]{3}{*}{ HDTMA (0.01)-U(VI)-P(V)- } & $30-155$ & 0.3 & 88.8 & 11.53 & Water elimination \\
\hline & $155-470$ & 14.55 & $247.3 ; 321.8 ; 437.5$ & $-440.2 ;-19.92$ & Decomposition and burning of organics \\
\hline & $470-950$ & 3.92 & $515.9\left(573.7^{*} \mathrm{q}\right)$ & $13.23\left(0.69^{\mathrm{q}}\right)$ & $\begin{array}{l}\text { Dehydroxylation/quartz polymorph transition and } \\
\text { burning of organics }\end{array}$ \\
\hline \multirow[t]{3}{*}{ HDTMA (0.0001)-P(V)- } & $30-155$ & 0.13 & 72.6 & 13.73 & Adsorbed and interlayer water elimination \\
\hline & $155-405$ & 1.5 & $298.7 ; 339.2$ & -144.8 & Decomposition and burning of organics \\
\hline & $405-950$ & 2.97 & $514.1\left(575.1^{* \mathrm{q}}\right)$ & $51.84\left(0.87^{\mathrm{q}}\right)$ & Dehydroxylation/quartz polymorph transition \\
\hline \multirow[t]{3}{*}{ HDTMA (0.001)-P(V)- } & $30-150$ & 0.14 & 77.2 & 2.568 & Water elimination \\
\hline & $150-420$ & 3.41 & $265.1 ; 340.1$ & -241.9 & Decomposition and burning of organics \\
\hline & $425-950$ & 4.15 & $519.4\left(574.2^{* \mathrm{q}}\right)$ & $52.1\left(0.48^{\mathrm{q}}\right)$ & $\begin{array}{l}\text { Dehydroxylation/quartz polymorph transition and } \\
\text { burning of organics }\end{array}$ \\
\hline \multirow[t]{3}{*}{ HDTMA (0.01)-P(V)- } & $30-120$ & 0.16 & 77 & 3.056 & Water elimination \\
\hline & $120-415$ & 8.07 & $253.2 ; 333.2$ & -300 & Decomposition and burning of organics \\
\hline & $415-950$ & 4.6 & $513.2\left(573.3^{* \mathrm{q}}\right)$ & $36.78\left(0.43^{\mathrm{q}}\right)$ & $\begin{array}{l}\text { Dehydroxylation/quartz polymorph transition and } \\
\text { burning of organics }\end{array}$ \\
\hline
\end{tabular}

$S$ structural rearrangements, $q$ quartz polymorph transition 

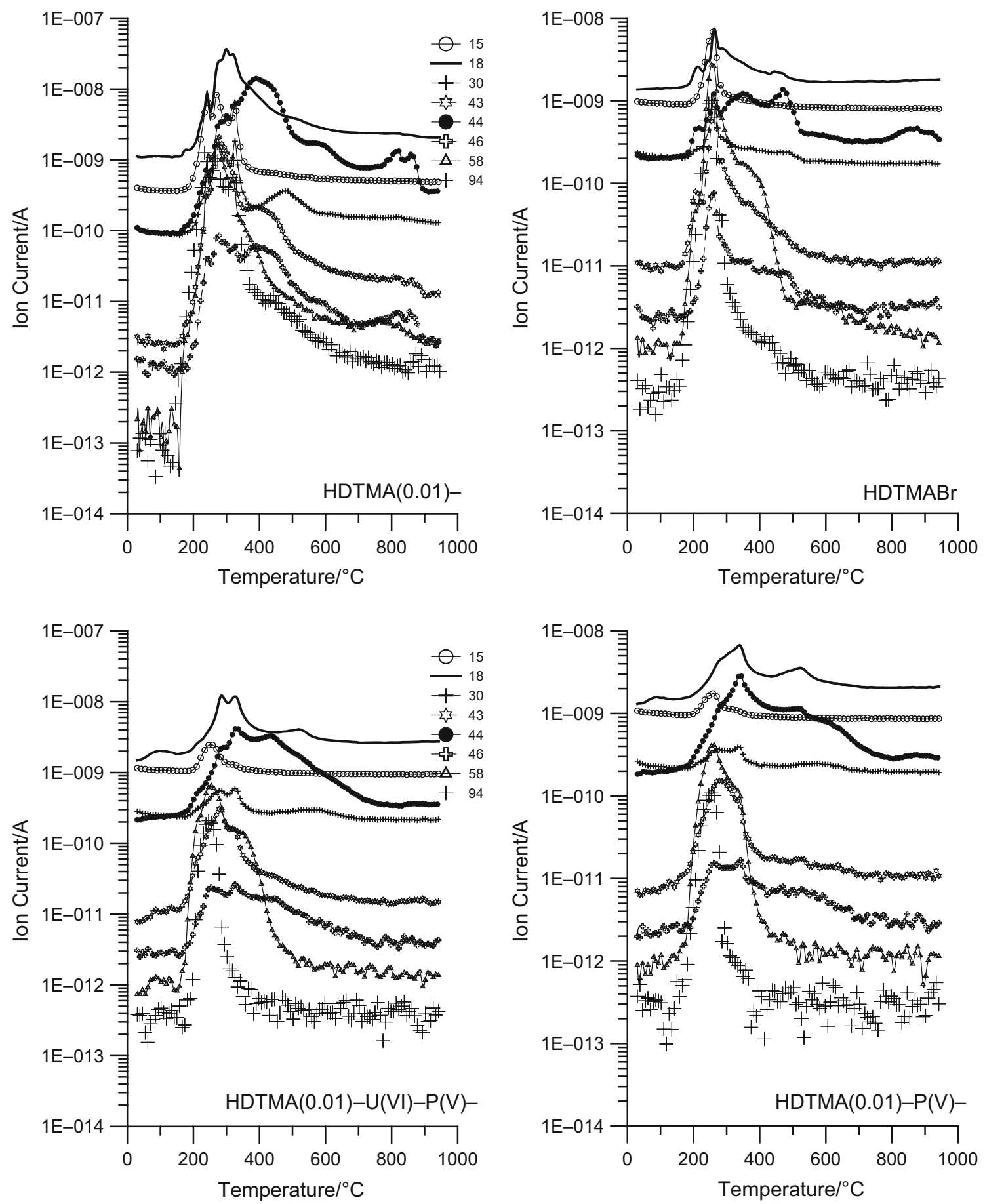

Fig. 6 MS profiles of gaseous products of defragmentation [15 $\left(\mathrm{CH}_{3}\right) ; 43$ (amine); $\left.58\left(\mathrm{NCH}_{2}\left(\mathrm{CH}_{3}\right)_{2}\right) ; 94\left(\mathrm{CH}_{3} \mathrm{Br}\right)\right]$ and oxidation [18 $\left(\mathrm{H}_{2} \mathrm{O}\right) ; 30$ (NO); $\left.44\left(\mathrm{CO}_{2}\right) ; 46\left(\mathrm{NO}_{2}\right)\right]$ characteristic for organoclay decomposition vs temperature

The position of the dehydroxylation peak is unaltered (Fig. 5). The endothermic character of the dehydroxylation reaction may be a response to the fact that dehydroxylation of the clay is not accompanied by oxidation of the surfactant. The data obtained from thermal analysis of all samples are summarized and compared in Table 2.
The MS spectra of the decomposition of U(VI) sorption products are shown in Fig. 6. The peaks originating from the $-\mathrm{CH}_{3}$ radical $(\mathrm{M} / \mathrm{Z}=15)$, amines $(43),-\mathrm{N}\left(\mathrm{CH}_{3}\right)_{2}$ $\mathrm{CH}_{2}(58)$, and $\mathrm{CH}_{3} \mathrm{Br}(58)$, appearing in the region between 200 and $450{ }^{\circ} \mathrm{C}$, provide evidence for the defragmentation of surfactant molecules [45-47]: via Hoffman 

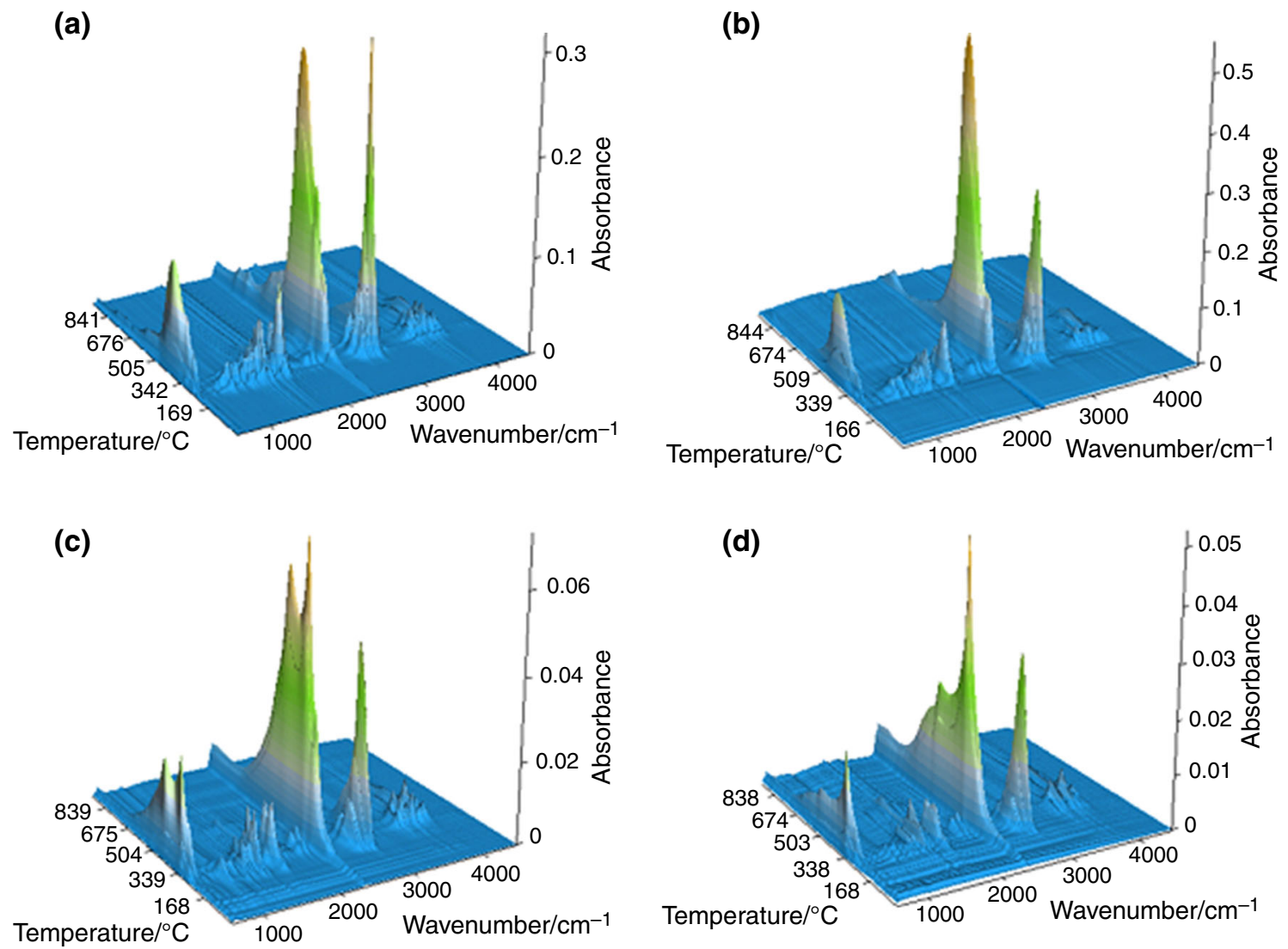

Fig. 7 FTIR-TG space image of HDTMA(0.01)- (a), HDTMA(0.01)-U(VI)- (b), HDTMA(0.01)-U(VI)-P(V)- (c), HDTMA-P(V)-clay (d) in air atmosphere

rearrangement and $\mathrm{S}_{\mathrm{N}}^{2}$ nucleophilic substitution. The peaks observable in the region $200-800{ }^{\circ} \mathrm{C}$ characteristic of $\mathrm{H}_{2} \mathrm{O}(\mathrm{M} / \mathrm{Z}=18), \mathrm{NO}(30), \mathrm{CO}_{2}(44)$, and $\mathrm{NO}_{2}(46)$ represent surfactant oxidation, which proceeds in two steps, between 200 and $400{ }^{\circ} \mathrm{C}$ and between 400 and $800{ }^{\circ} \mathrm{C}$. The first step regards the surfactant sorbed on the mineral surface via electrostatic and covalent forces, whereas the second one relates to the surfactant present in the interior of the mineral structure, bound by electrostatic forces.

\section{Spectral characterization of sorption products}

FTIR spectra of the sorption products in the gaseous phase are given in Fig. 7 The increase in temperature results, at first, in the appearance of surfactant defragmentation products. The band at $2933 \mathrm{~cm}^{-1}$ indicates stretching vibrations of $\mathrm{CH}_{2}$ groups, and the band at $1460 \mathrm{~cm}^{-1}$ originates from scissoring vibrations of methylene groups. Apart from that, there is a prominent band at $2360 \mathrm{~cm}^{-1}$ characteristic of $\mathrm{CO}_{2}$ and a peak at $1750 \mathrm{~cm}^{-1}$ characteristic of stretching vibrations of $\mathrm{C}=\mathrm{O}$ (carbonyl) groups or $\mathrm{N}=\mathrm{O}$ stretching vibrations of $\mathrm{NO}_{2}$. Both of these bands are evidence for a stepwise transition from defragmentation to oxidation of HDTMA. For temperatures above $400{ }^{\circ} \mathrm{C}$, oxidation clearly prevails over defragmentation.

Detailed data on changes in the position of the peaks with temperature are given in Fig. 8 and Table 3. An analysis of the peaks at 1464, 1750, 2933 leads to the conclusion that the pure surfactant (HDTMA-Br) decomposes weakly, as the temperature of the peak maximum is lower than the decomposition temperatures of the clay modifications. This observation demonstrates that interaction in HDTMA-Br is exclusively covalent.

The peak at $2181 \mathrm{~cm}^{-1}$, characteristic of carbon monoxide, changes its position in a fashion indicating that the oxidation of the surfactant is a multistage process. It seems that there are different sorption sites in the structure of the clay, with the surfactant molecules either deposited on the mineral surface or hidden in the structural pores. This means that the surfactant molecules less strongly bound by the clay matrix are more easily oxidized. Also, the enthalpy of $\mathrm{CO}$ formation is lower than for $\mathrm{CO}_{2}$; therefore, oxidation of the surfactant in the case of $\mathrm{CO}$ formation is less spontaneous than when $\mathrm{CO}_{2}$ is formed. 
Fig. 8 FTIR evolution profiles of the characteristic signal: $2937 \mathrm{~cm}^{-1}\left(\mathrm{CH}_{2}\right), 2366 \mathrm{~cm}^{-1}$ $\left(\mathrm{CO}_{2}\right), 1181 \mathrm{~cm}^{-1}(\mathrm{CO})$ $1750 \mathrm{~cm}^{-1}(\mathrm{C}=\mathrm{O}$ in carbonyl groups), $1464 \mathrm{~cm}^{-1}\left(\mathrm{CH}_{2}\right)$
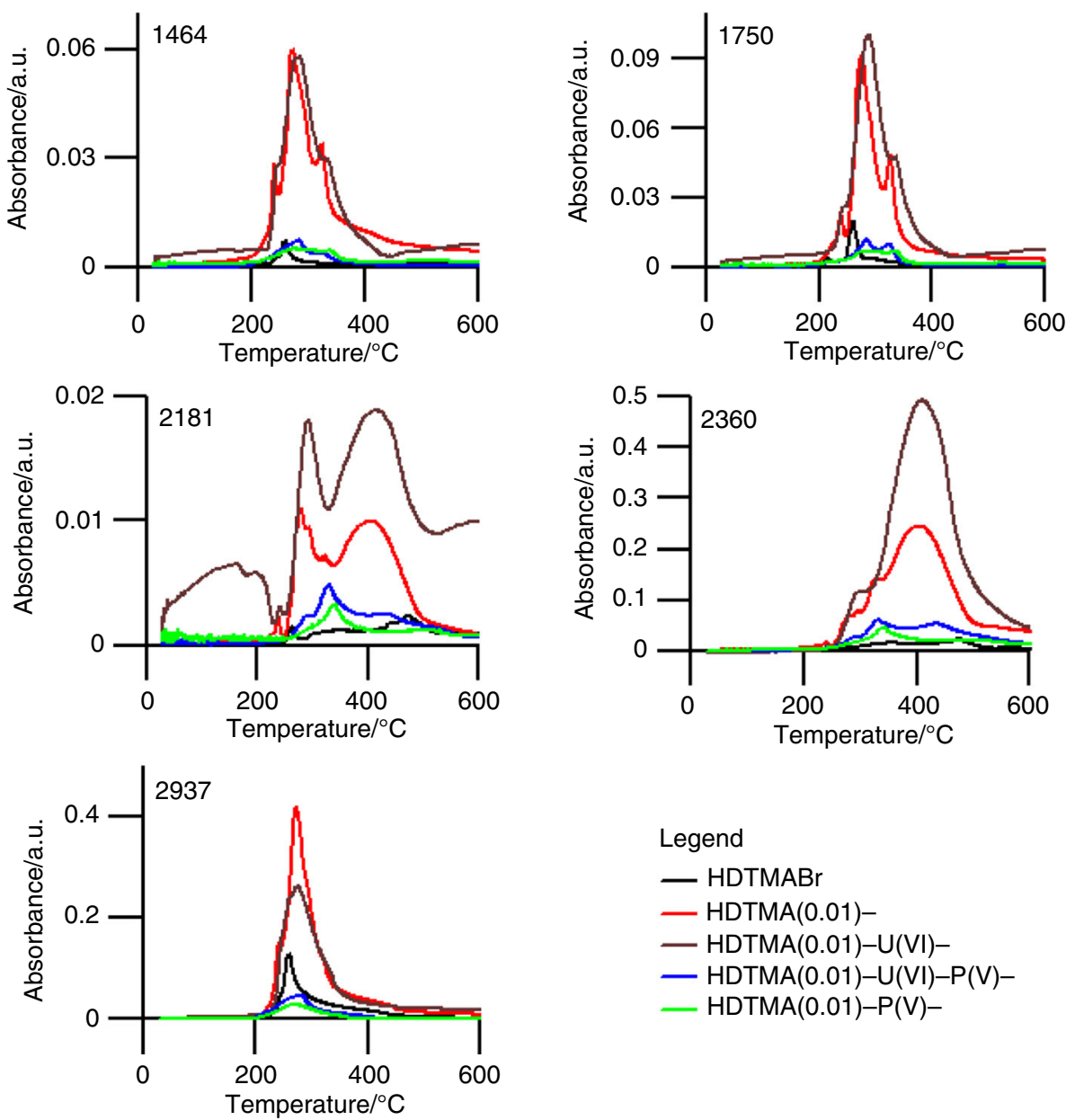

Legend

- HDTMABr

$-\operatorname{HDTMA}(0.01)-$

- $\operatorname{HDTMA}(0.01)-\mathrm{U}(\mathrm{VI})-$

- $\operatorname{HDTMA}(0.01)-\mathrm{U}(\mathrm{VI})-\mathrm{P}(\mathrm{V})-$ - HDTMA (0.01)-P(V)-

Table 3 Peak temperatures on the infrared spectrums

\begin{tabular}{llllll}
\hline Wavenumber $/ \mathrm{cm}^{-1}$ & \multicolumn{3}{l}{$T_{\text {peaks }}{ }^{\circ}{ }^{\circ} \mathrm{C}$} & & \\
\cline { 2 - 6 } & HDTMA-Br & HDTMA- & HDTMA-U(VI)- & HDTMA-P(IV)- & HDTMA-U(VI)-P(IV)- \\
\hline 1464 & 259 & $238 ; 270 ; 318$ & 282 & $277 ; 334$ & $280 ; 322$ \\
1750 & $214 ; 260$ & $237 ; 274 ; 320$ & 288 & $284 ; 334$ & $283 ; 323$ \\
2181 & $261 ; 471$ & $239 ; 278 ; 406$ & $161 ; 291 ; 408$ & $339 ; 505$ & $328 ; 430$ \\
2360 & $262 ; 353 ; 471$ & 405 & 409,870 & 340 & $331 ; 431$ \\
2933 & 260 & 273 & 274 & 267 & 280 \\
\hline
\end{tabular}

The temperature sequence HDTMA-U(VI)-P(V)-clay < HDTMA-P(V)-clay for the peak maxima at 2181 and 2360 is intriguing. It seems possible that in the case of HDTMA$\mathrm{P}(\mathrm{V})$-clay some part of the surfactant occurs in the form of alkylammonium phosphate, unlike in the HDTMA-U(VI)$\mathrm{P}(\mathrm{V})$-clay system, where phosphate ions are "exploited" to form complexes with U(VI) ions. Apart from that, U(VI) ions interact with the oxygens of the sorbent framework, and therefore, the temperatures of defragmentation and oxidation (peaks at 1464,2181 , and $2360 \mathrm{~cm}^{-1}$ ) of
HDTMA-U(VI)-P(V)-clay are lower than those of HDTMA-P(V)-clay.

FTIR spectra of the sorption products in the solid phase (clay phase) are given in Fig. 9. There is a remarkable downfall shift of the $\mathrm{Si}-\mathrm{O}$ stretching vibration band from 1111 to $1032 \mathrm{~cm}^{-1}$ with an increase in $\mathrm{HDTMA}_{\text {in }}$ concentration from 0.0001 to $0.01 \mathrm{~mol} \mathrm{dm}^{-3}$ for the $\mathrm{P}(\mathrm{V})$ HDTMA-clay system. This probably is a consequence of the replacement of the weak interaction between hydrophilic $\mathrm{P}(\mathrm{V})$ ions and negatively charged siloxane oxygens 
Fig. 9 FTIR spectra of solid phase of sorption products
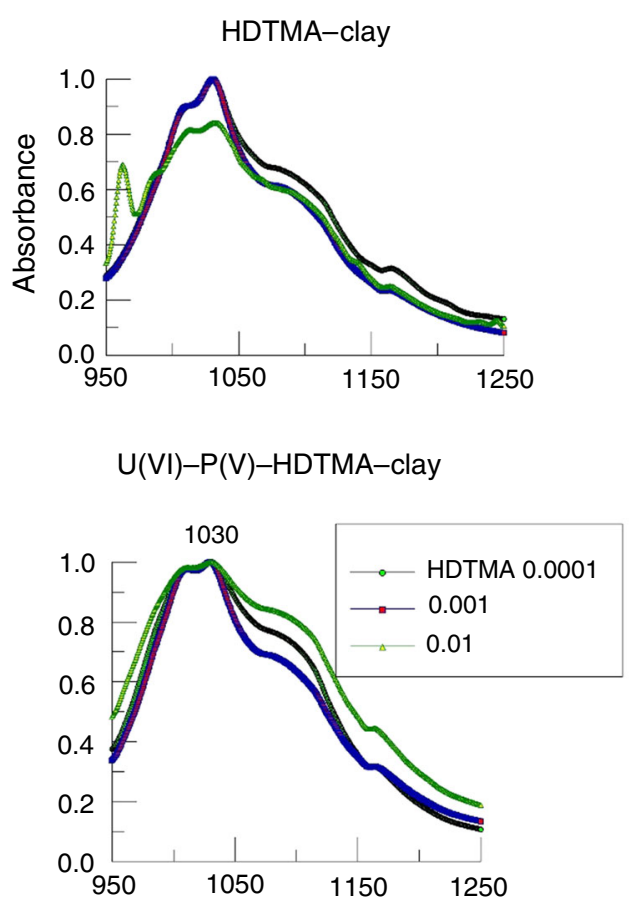
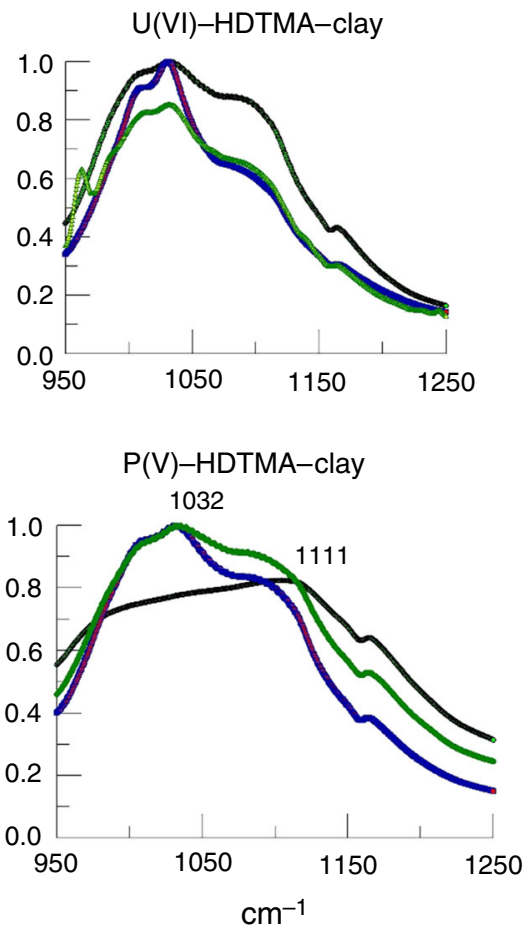

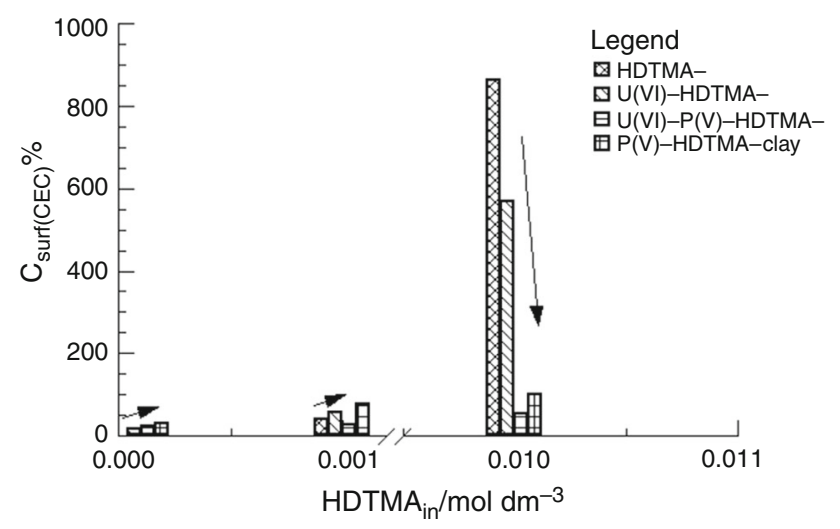

Fig. 10 Changes in sorption of HDTMA with initial concentration HDTMA $_{\text {in }}$

by the strong interaction of hydrophobic $\mathrm{HDTMA}^{+}$cations with $\mathrm{Si}-\mathrm{O}$ structural units of clay. For the U(VI)-P(V)HDTMA-clay system, the position of the Si-O vibration band remains stable. This means that $\mathrm{U}(\mathrm{VI})$ and $\mathrm{P}(\mathrm{V})$ ions interact on the clay surface to form a phosphate complex that strongly interacts with $\mathrm{Si}-\mathrm{O}$ units.

\section{HDTMA sorption equilibrium data}

The percentages of sorption of HDTMA $\left[\mathrm{c}_{\mathrm{CEC}(\mathrm{surf})}\right]$ from the aqueous to the sorbent phase are given in Fig. 10. For HDTMA $_{\text {in }}(0.0001), \mathrm{c}_{\mathrm{CEC}(\text { surf) }}$ increases when going from HDTMA- to HDTMA-U(VI) to HDTMA-U(VI)-P(V)- to HDTMA-P(V)-clay. This demonstrates that HDTMA interacts with $\mathrm{P}(\mathrm{V})$ ions in the sorbent phase. For HDTMA $_{\text {in }}(0.001), \mathrm{C}_{\mathrm{CEC}(\text { surf })}$ increases when going from HDTMA- to HDTMA-U(VI) to HDTMA-P(V)- to HDTMA-clay. This sequence does not include the HDTMA-U(VI)-P(V)-clay system because the presence of $\mathrm{U}(\mathrm{VI})$ ions interacting with $\mathrm{P}(\mathrm{V})$ ions prevents interaction between HDTMA and $\mathrm{P}(\mathrm{V})$ in the sorbent phase. For HDTMA $_{\text {in }}(0.01)$, the sudden decrease in $\mathrm{C}_{\mathrm{CEC} \text { (surf) }}$ results from the decomposition of the bilayer of surfactant cations (clay-(HDTMA $)_{2}^{+}$) by both $\mathrm{P}(\mathrm{V})$ ions and the phosphate complex of U(VI).

\section{$\mathrm{U}(\mathrm{VI})$ sorption equilibrium data: the influence of $\mathrm{pH}$}

The distribution constants of U(VI) between the aqueous and the sorbent phase, defined as $K_{\mathrm{d}}=c_{\mathrm{s}} / c_{\mathrm{aq}}$, are given in Fig. 11a. There is a visible improvement in U(VI) sorption over the entire $\mathrm{pH}$ range in the presence of $\mathrm{P}(\mathrm{V})$ ions in the aqueous phase. The general trend of the increase in $\log \mathrm{K}_{\mathrm{d}}$ is very complex as it reflects the existence of a vast array of different species formed in both the aqueous and the solid phases (Fig. 11b). The hypothetical composition of the aqueous and solid phases was estimated using Medusa software [48]. The results suggested that the solid phase was composed, among others, of $\left(\mathrm{UO}_{2}\right)_{3}\left(\mathrm{PO}_{4}\right)_{2} 4 \mathrm{H}_{2} \mathrm{O}$ and $\mathrm{UO}_{2}(\mathrm{OH})_{2} \mathrm{H}_{2} \mathrm{O}$ and that the equilibrium aqueous phase contained several acetate and carbonate complexes. The species distribution diagrams obtained are idealized, however. In our recent paper [29], we strongly emphasized that 

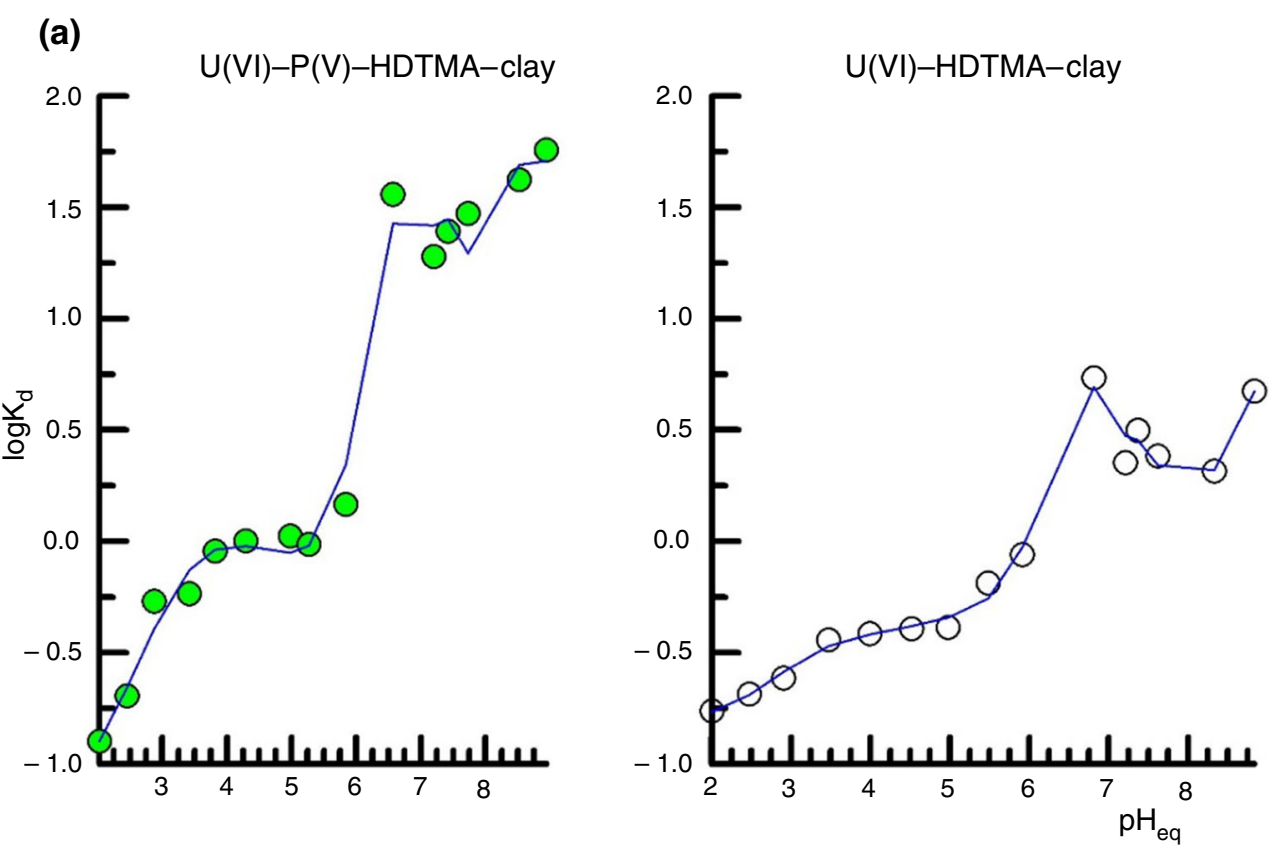

(b)

$$
\begin{aligned}
& {\left[\mathrm{CH}_{3} \mathrm{COO}^{-}\right]_{\text {Tот }}=100.00 \mathrm{mM}} \\
& {\left[\mathrm{UO}_{2}{ }^{2+}\right]_{\text {Tот }}=0.50 \mathrm{mM}}
\end{aligned}
$$

$$
\begin{aligned}
\log \mathrm{P}_{\mathrm{CO}_{2}} & =-3.50 \\
{\left[\mathrm{PO}_{4}{ }^{3-}\right]_{\mathrm{TOT}} } & =0.10 \mathrm{mM}
\end{aligned}
$$

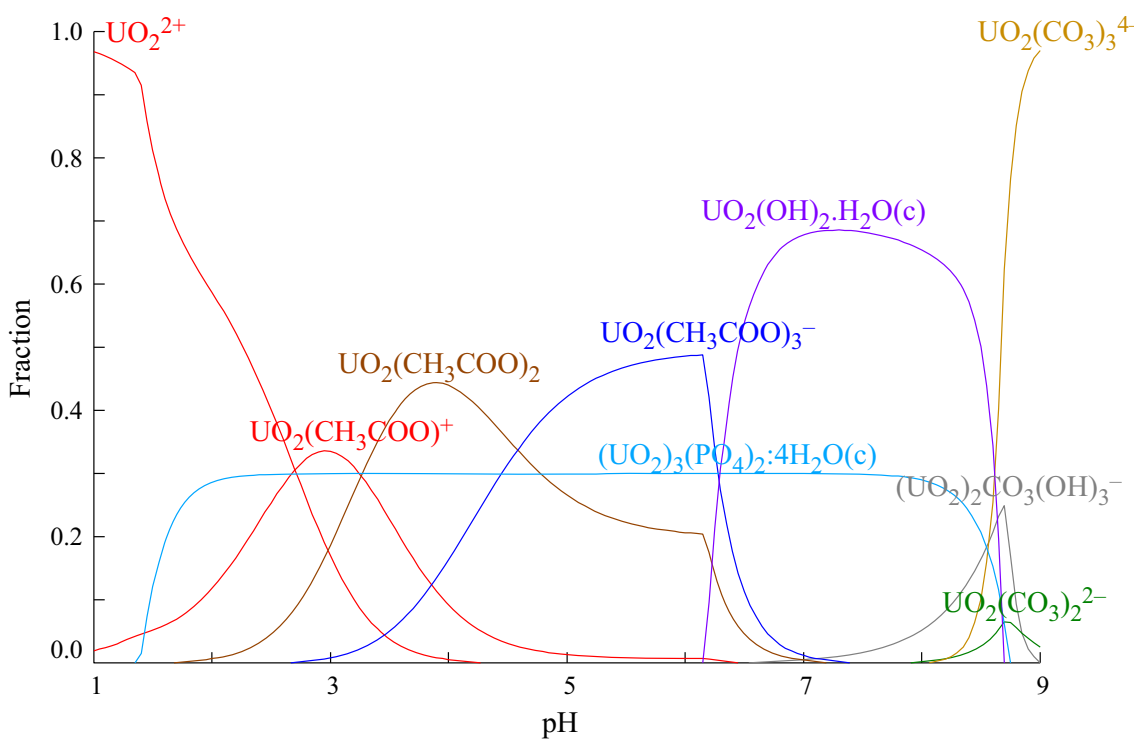

Fig. 11 Influence of $\mathrm{pH}$ on U(VI) sorption on HDTMA-clay

the sorbent phase contained at least two different $\mathrm{U}(\mathrm{VI})$ phosphate complexes with a $\mathrm{U}(\mathrm{VI}) / \mathrm{P}(\mathrm{V})$ ratio in the range of 1.1-1.5 or 3.3-3.8. At the same time, we excluded the possibility of $\left(\mathrm{UO}_{2}\right)_{3}\left(\mathrm{PO}_{4}\right)_{2} 4 \mathrm{H}_{2} \mathrm{O}$ being formed, based on the analysis of the concentrations of $\mathrm{U}(\mathrm{VI})$ and $\mathrm{P}(\mathrm{V})$ ions in the equilibrium aqueous phase. By contrast, the presence of anionic acetate and carbonate complexes in the aqueous phase is unquestionable, and these species probably interact with the positively charged bilayer of surfactant cations anchored on the mineral surface in the form of clay(HDTMA $)_{2}^{+}$. The 'mysterious' minimum $\log K_{\mathrm{d}}$ value at $\mathrm{pH}$ 8 may be related to the lower distribution constant of $\left(\mathrm{UO}_{2}\right)_{2} \mathrm{CO}_{3}(\mathrm{OH})_{3}^{-}$when compared with the $\mathrm{UO}_{2}\left(\mathrm{CO}_{3}\right)_{3}^{4-}$ species. In turn, the increase in $\log K_{\mathrm{d}}$ at $\mathrm{pH} 9$ is a result of the formation of sodium uranate $\mathrm{Na}_{2} \mathrm{U}_{2} \mathrm{O}_{7}$ in the sorbent phase [6]. 


\section{Conclusions}

The thermal analysis of the products of modification of red clay with HDTMA revealed the following temperature regions in the DTG curves: dehydration, defragmentation/ oxidation, oxidation/dehydroxylation. The HDTMA$\mathrm{U}(\mathrm{VI})-\mathrm{P}(\mathrm{V})$-clay system differs from the remaining clay modifications in the defragmentation/oxidation region, which shows more DTG peaks, indicating that there is mutual interaction among $\mathrm{U}(\mathrm{VI}), \mathrm{P}(\mathrm{V})$, and $\mathrm{HDTMA}^{+}$ cations, an observation that is supported by the differences in the FTIR spectra of HDTMA-P(V)- and HDTMA$\mathrm{U}(\mathrm{VI})-\mathrm{P}(\mathrm{V})$-clay.

The MS and FTIR gaseous phase spectra of thermal decomposition of U(VI) sorption products reveal that oxidation of the surfactant is a multistage process. Moreover, the higher temperature of defragmentation/oxidation observed for HDTMA-P(V)- compared with HDTMA$\mathrm{U}(\mathrm{VI})-\mathrm{P}(\mathrm{V})$-clay indicates the probable formation of alkylammonium phosphates in the first case and interaction of U(VI) ions with oxygen atoms of the sorbent framework in the second case.

Open Access This article is distributed under the terms of the Creative Commons Attribution 4.0 International License (http://creative commons.org/licenses/by/4.0/), which permits unrestricted use, distribution, and reproduction in any medium, provided you give appropriate credit to the original author(s) and the source, provide a link to the Creative Commons license, and indicate if changes were made.

\section{References}

1. Oyanedel-Craver VA, Fuller M, Smith JA. Simultaneous sorption of benzene and heavy metals onto two organoclays. J Colloid Interface Sci. 2007;9(2):485-92.

2. Oyanedel-Craver VA, Smith JA. Effect of quaternary ammonium cation loading and $\mathrm{pH}$ on heavy metal sorption to $\mathrm{Ca}$ bentonite and two organobentonites. J Hazard Mater. 2006;137(2):1102-14.

3. Yuan G. Natural and modified nanomaterials as sorbents of environmental contaminants. J Environ Sci Health Part A Toxic Hazard Subst Environ Eng A. 2004;39(10):2661-70.

4. Lee T, Choi J, Park J-W. Simultaneous sorption of lead and chlorobenzene by organobentonite. Chemosphere. 2002;49:1309-15.

5. Yoo J-Y, Choi J, Lee T, Park J-W. Organobentonite for sorption and degradation of phenol in the presence of heavy metals. Water Air Soil Pollut. 2004;154:225-37.

6. Liu J, Zhao C, Tu H, Yang J, Li F, Li D, Liao J, Yang Y, Tang J, Liu N. U(VI) adsorption onto cetyltrimethylammonium bromide modified bentonite in the presence of $\mathrm{U}(\mathrm{VI})-\mathrm{CO}_{3}$ complexes. Appl Clay Sci. 2017;135:64-74.

7. Majdan M, Pikus S, Gajowiak A, Sternik D, Zięba E. Uranium sorption on bentonite modified by octadecyltrimethylammonium bromide. J Hazard Mater. 2010;184(1-3):662-7.
8. Bampaiti A, Misaelides P, Noli F. Uranium removal from aqueous solutions using a raw and HDTMA-modified phillipsitebearing tuff. J Radioanal Nucl Chem. 2015;303:2233-41.

9. Wang Y-Q, Zhang Z-B, Li Q, Liu Y-H. Adsorption of uranium from aqueous solution using $\mathrm{HDTMA}^{+}$-pillared bentonite: isotherm, kinetic and thermodynamic aspects. J Radioanal Nucl Chem. 2012;293:231-9.

10. Sprynskyya M, Kovalchuka I, Buszewski B. The separation of uranium ions by natural and modified diatomite from aqueous solution. J Hazard Mater. 2010;181:700-7.

11. Matijašević S, Daković A, Tomašević-Čanović M, Stojanović M, Ileš D. Uranium(VI) adsorption on surfactant modified heulandite/clinoptilolite rich tuff. J Serb Chem Soc. 2006;71(12):1323-31.

12. Gajowiak A, Gładysz-Płaska A, Sternik D, Pikus S, Sabah E, Majdan M. Sorption of uranyl ions on organosepiolite. Chem Eng J. 2013;219:459-68.

13. Bors J. Sorption and desorption of radioiodine on organo-clays. Radiochim Acta. 1992;58-59:235-8.

14. Bors J, Gorny A, Dultz S. Iodide, caesium and strontium adsorption by organophilic vermiculite. Clay Miner. 1997;32:21-8.

15. Li D, Kaplan D, Seaman JC, Powell BA, Sams A, Heald S, Chengjun S. (327b) Effective removal of pertechnetate (TcO4-), iodide (I-) and iodate (IO3-) from groundwater by organoclays and granular activated carbon. https://www.aiche.org/con ferences/aiche-annual-meeting/2017/proceeding/paper/327beffective-removal-pertechnetate-tco4-iodide-i-and-iodate-io3groundwater-organoclays-and. Materials from the AIChE Annual Meeting, 2017.

16. Şimşek S, Baybaş D, Koçyiğit M, Yıldırım H. Organoclay modified with lignin as a new adsorbent for removal of $\mathrm{Pb}^{2+}$ and $\mathrm{UO}_{2}{ }^{2+}$. J Radioanal Nucl Chem. 2014;299:283-92.

17. Kulik D, Curti E, Berner U. Thermodynamic modelling of radionuclide retention in clays: surface complexation or solid solution equilibria ? In: International meeting, December 9-12, 2002, Reims, France clays in natural and engineered barriers for radioactive waste confinement, O-5a-1; pp. 63-4.

18. Riebe B, Bunnenberg C. Retention of anionic radionuclides by natural and organophilic clays in high-molar saline solutions. In: International meeting, December 9-12, 2002, Reims, France clays in natural and engineered barriers for radioactive waste confinement, O-5a-3; p. 67-8.

19. Bors J, Dultz S, Riebe B. Organophilic bentonites as adsorbents for radionuclides. I. Adsorption of anionic and cationic fission products. Appl Clay Sci. 2000;16:1-13.

20. Riebe B, Bors J, Dultz S. Retardation capacity of organophilic bentonite for anionic fission products. J Contam Hydrol. 2001;47:255-64.

21. Riebe B, Bunnenberg C, Erten HN. Influence of temperature and composition of electrolytes on iodide sorption by organophilic clays. In: 8th international conference on chemistry and migration behaviour of actinides and fission products in the geosphere, Bregenz, Österreich, 16-21.09.2001, Poster.

22. Zhang H, Kim YK, Hunter TN, Brown AP, Lee JW, Harbottle D. Organically modified clay with potassium copper hexacyanoferrate for enhanced $\mathrm{Cs}^{+}$adsorption capacity and selective recovery by flotation. J Mater Chem A. 2017;5:15130-43.

23. Wu T, Amayri S, Drebert J, Van Loon LR, Reich T. Neptunium $(\mathrm{V})$ sorption and diffusion in opalinus clay. Environ Sci Technol. 2009;43:6567-71.

24. Wang T-H, Li M-H, Yeh W-C, Wei Y-Y, Teng S-P. Removal of cesium ions from aqueous solution by adsorption onto local Taiwan laterite. J Hazard Mater. 2008;160:638-42.

25. Wang T-H, Hsieh C-J, Lin S-M, Wu D-C, Li M-H, Teng S-P. Effect of alkyl properties and head groups of cationic surfactants 
on retention of cesium by oragnoclays. Environ Sci Technol. 2010;44(13):5142-7.

26. Koh S-M, Dixon JB. Preparation and application of organominerals as sorbents of phenol, benzene and toluene. Appl Clay Sci. 2001;18:111-22.

27. Zeng QH, Yu AB, Lu GQ, Standish RK. Molecular dynamics simulation of the structural and dynamic properties of dioctadecyldimethyl ammoniums in organoclays. J Phys Chem B. 2004;108:10025-33.

28. Bickford J, Foote M, Taylor P. Sorbents testing for the solidification of organic process waste streams from the Radiochemical Engineering Development Center at Oak Ridge National Laboratory, WM2008 conference, February 24-28, 2008, Phoenix, AZ, Abstract 8114.

29. Sternik D, Gładysz-Płaska A, Grabias E, Majdan M, Knauer W. A thermal, sorptive and spectral study of HDTMA-bentonite loaded with uranyl phosphate. $\mathrm{J}$ Therm Anal Calorim. 2017;129:1277-89.

30. Yariv S. The role of charcoal on DTA curves of organo-clay complexes: an overview. Appl Clay Sci. 2004;24:225-36.

31. Yariv S, Lapides I, Borisover M. Thermal analysis of tetraethylammonium and benzyltrimethylammonium montmorillonites. J Therm Anal Calorim. 2012;110:385-94.

32. Borisover M, Bukhanovsky N, Lapides I, Yariv S. The potential of thermally treated organobentonites to adsorb organic compounds from water. Appl Clay Sci. 2012;67-68:151-57.

33. Lapides I, Borisover M, Yariv S. Thermal analysis of hexadecyltrimethylammonium-Montmorillonites, Part 1. Thermogravimetry, carbon and hydrogen analysis and thermo-IR spectroscopy Analysis. J Therm Anal Calorim. 2011;105:921-9.

34. Lapides I, Borisover M, Yariv S. Thermal analysis of hexadecyltrimethylammonium-montmorillonites: Part 2. Thermo-XRDspectroscopy-analysis. J Therm Anal Calorim. 2011;105:39-51.

35. He H, Ding Z, Zhu J, Yuan P, Xi Y, Yang D, Frost RL. Thermal characterization of surfactant-modified Montmorillonites. Clay Clay Miner. 2005;53(3):287-93.

36. Park Y, Frost RL, Ayoko GA, Morgan DL. Adsorption of p-nitrophenol on organoclays: A thermoanalytical study. J Therm Anal Calorim. 2013;111:41-7.
37. Park Y, Ayoko GA, Kristof J, Horváth E, Frost RL. A thermoanalytical assessment of an organoclay. J Therm Anal Calorim. 2012;107:1137-42.

38. Gładysz-Płaska A, Majdan M, Sternik D, Pikus S, Zięba E. Sorptive and thermal properties of red clay in relation to $\mathrm{Cr}(\mathrm{VI})$. J Therm Anal Calorim. 2010;101:775-8.

39. Aran D, Maul A, Masfraud JF. A spectrophotometric measurement of soil cation exchange capacity based on cobaltihexamine chloride complex. C R Geosci. 2008;340(12):865-71.

40. Budnyak TM, Yanovska ES, Kołodyńska D, Sternik D, Pylypchuk V, Ischenko MV, Tertykh VA. Preparation and properties of organomineral adsorbent obtained by sol-gel technology. J Therm Anal Calorim. 2016;125:1335-51.

41. Marczenko Z, Balcerzak M. Spektrofotometryczne metody w analizie chemicznej. Warszawa: Wydawnictwo Naukowe PWN; 1998. p. 465.

42. Mothé CG, Ambrósio MCR. Processes occurring during the sintering of porous ceramic materials by $\mathrm{tg} / \mathrm{dsc}$. J Therm Anal Calorim. 2007;87:819-22.

43. Moore GSM. The $\alpha-\beta$ inversion in submilligram particles of natural quartz. J Therm Anal. 1993;40:115-20.

44. Majdan M, Pikus S, Rzączyńska Z, Iwan M, Maryuk O, Kwiatkowski R, Skrzypek H. Characteristics of chabazite modified by hexadecyltrimethylammonium bromide and of its affinity toward chromates. J Mol Struct. 2006;791:53-60.

45. Cervantes-Uc JM, Cauich-Rodríguez JV, Vázquez-Torres $H$, Garfias-Mesías LF, Paul DR. Thermal degradation of commercially available organoclays studied by TGA-FTIR. Thermochim Acta. 2007;457:92-102.

46. Xie W, Gao Z, Pan W, Hunter D, Singh A, Vaia R. Thermal degradation chemistry of alkyl quaternary ammonium montmorillonite. Chem Mater. 2001;13:2979-90.

47. Bellucci F, Camino G, Frache A, Sarra A. Catalytic charringvolatilization competition in organoclay nanocomposites. Polym Degrad Stab. 2007;92:425-36.

48. Medusa-Hydra chemical equilibrium software for Windows. www.kth.se/che/medusa. 